\section{Journal of Home \\ Economics}

مجلة الاقتصاد المنزلي

مجلد 24- العدد الأول - 2014م الأهني

http://homeEcon.menofia.edu.eg

ISSN 1110-2578

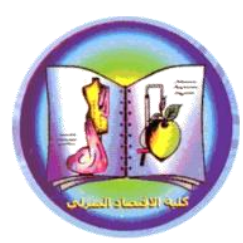

\title{
الإفادة من بقايا بعض الأقمشة باستخدام النسيج اليدوي في إثراء ملابس الطفل \\ ومكملاتها
}

\author{
نورا حسن إبراهيم العدوى التهي
}

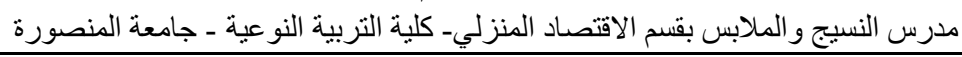

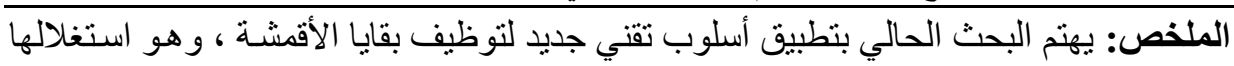

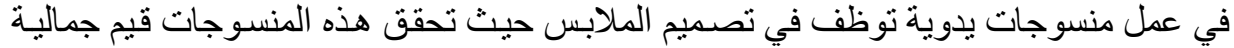

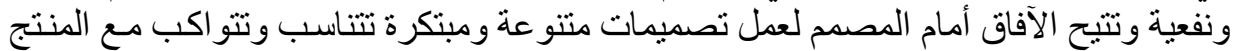

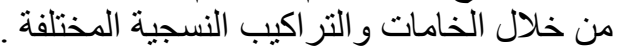

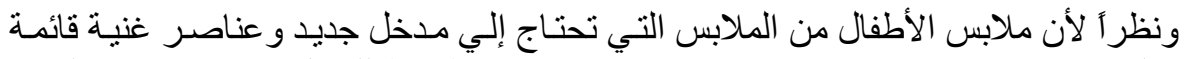

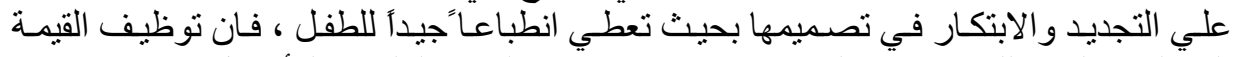

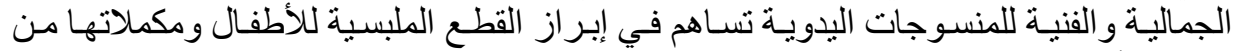
خلال التأثير ات النسجية و اللونية المختلفة . لالتئة

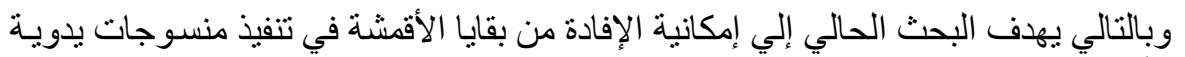

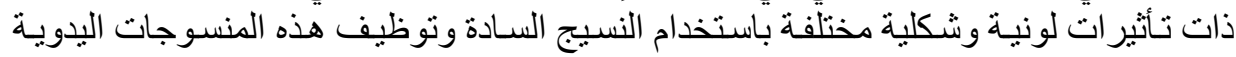

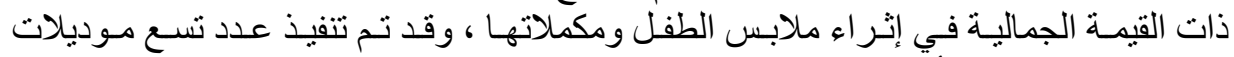

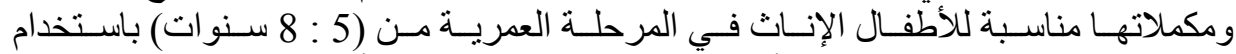

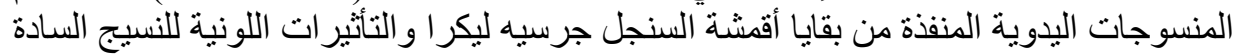

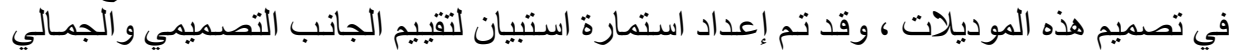

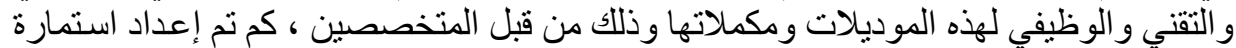

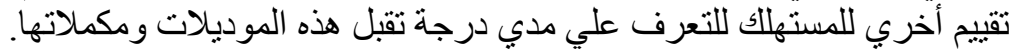

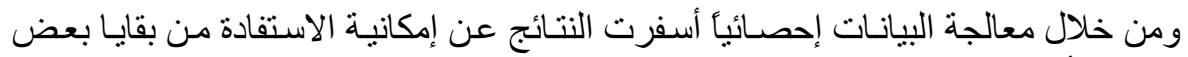

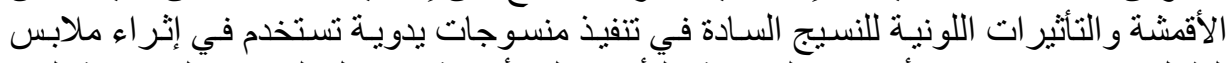

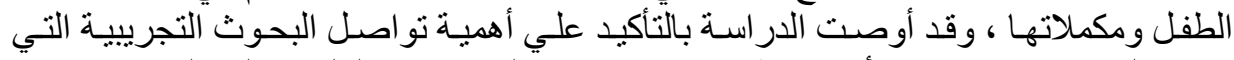

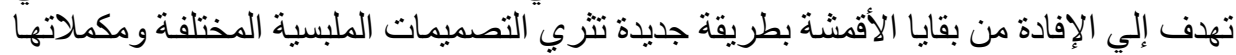

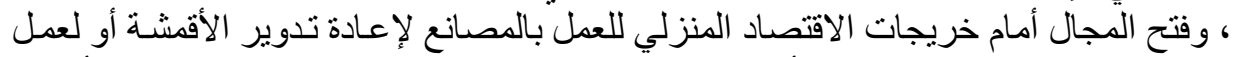

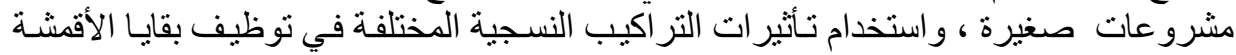

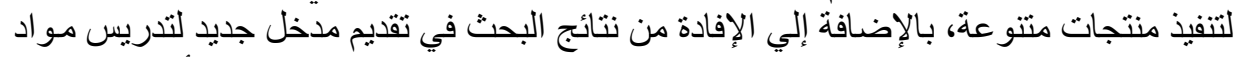

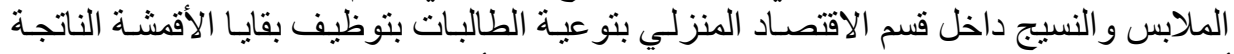

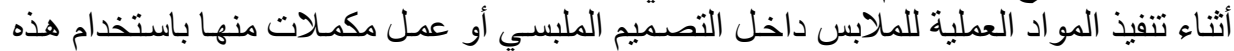

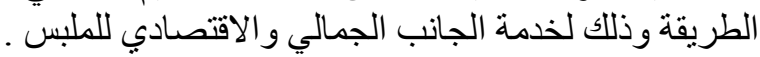


بالر غم من التقدم التكنولوجي الذي لحق بصناعة التهاعل الملابس و النسيج إلا أن هناك عملية إهدار

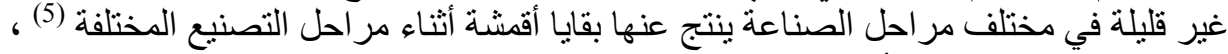

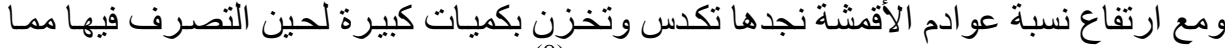

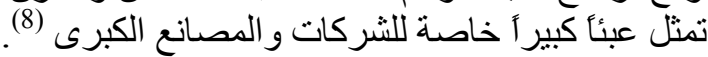

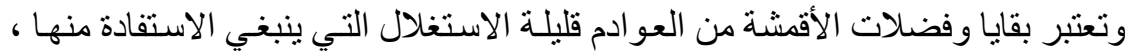

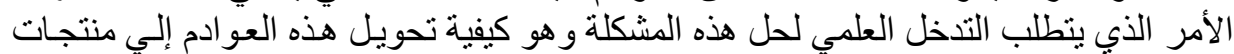

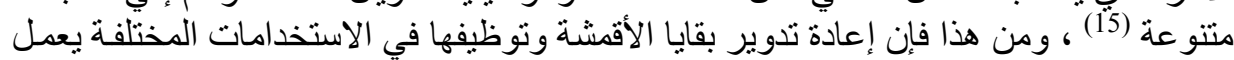

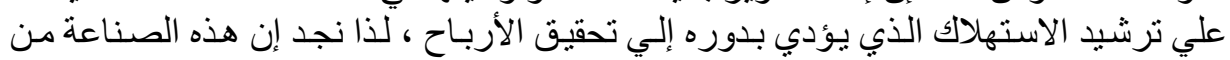

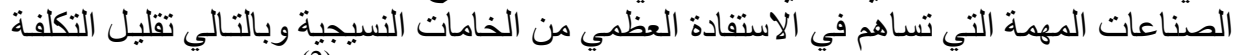

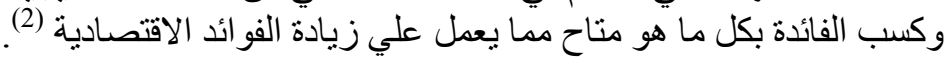

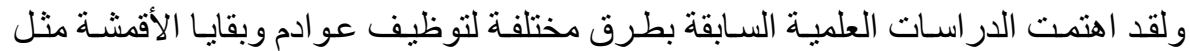

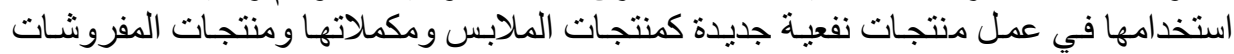

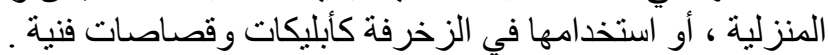

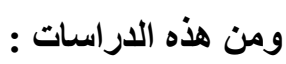

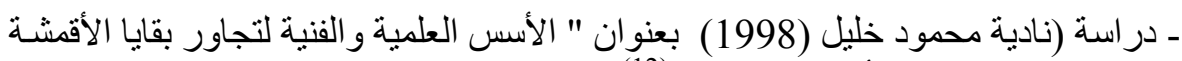
في تنفيذ مكملات ملابس بالأسر المنتجة ") (19) (12)

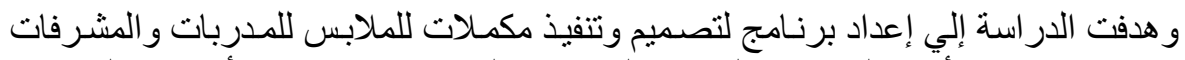

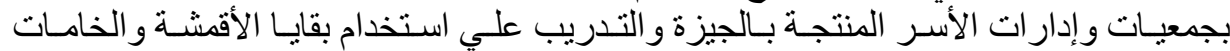

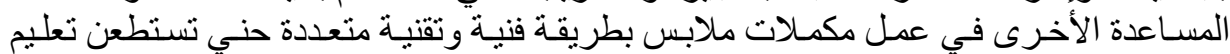

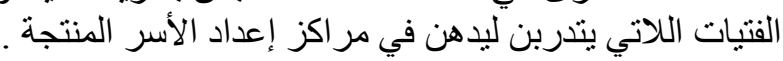
ـ دراسة (أنرف عبد الفتاح مصطفي (2005) بعنوان " بو اقي المنسوجات ولغنة التعبير الفني ") (1)

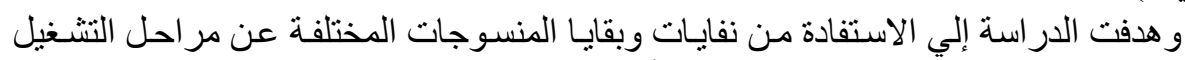

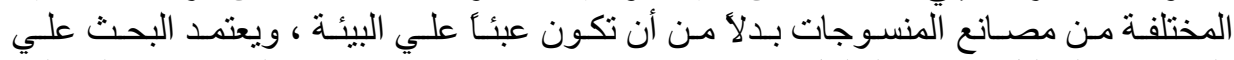

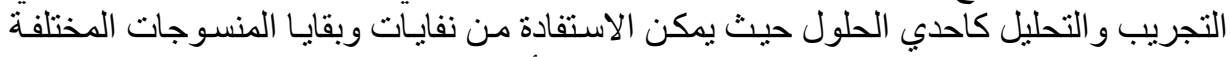

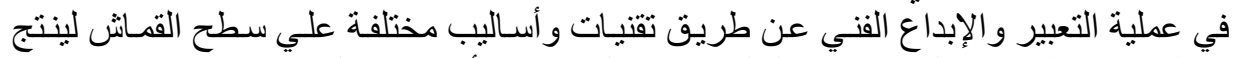

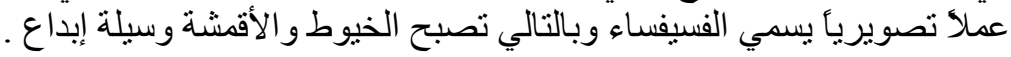

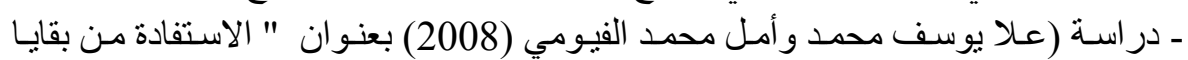

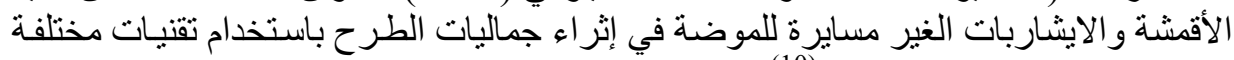

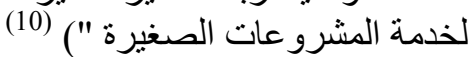

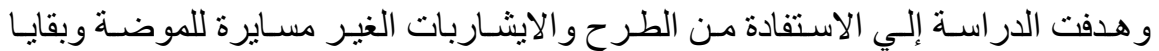

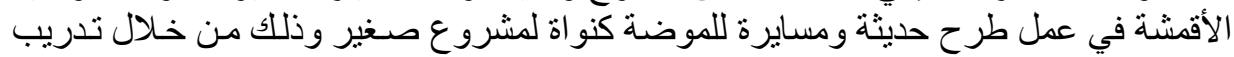

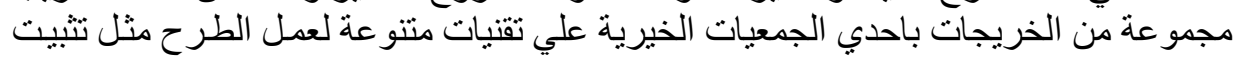

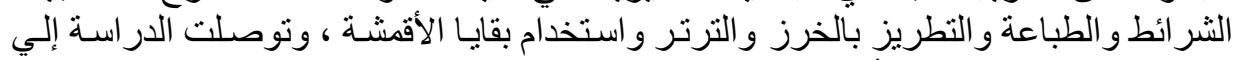

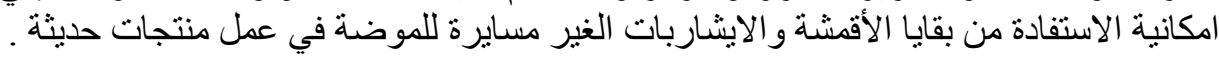


مجلة الاقتصاد المنزلى - مجلد 24 العدد الأول - 2014

ـ دراسة (أميرة عبد اله نور الدين (2010) بعنوان " تصميم مفروشات بالزخارف النباتيـة

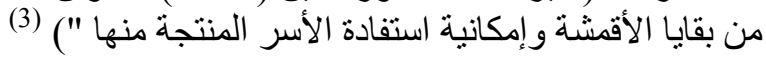

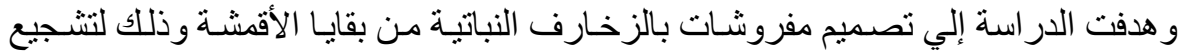

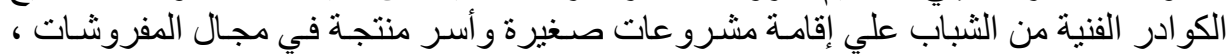

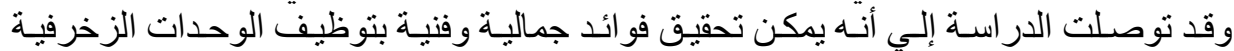

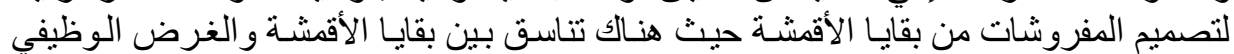

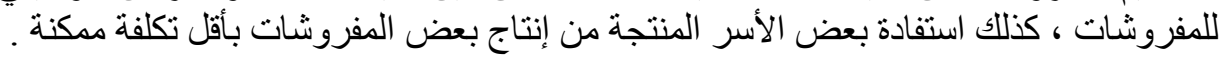

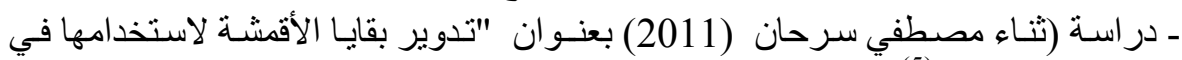

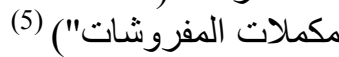

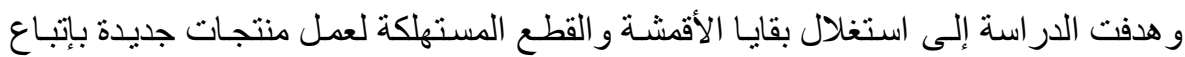

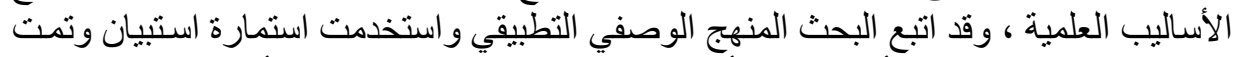

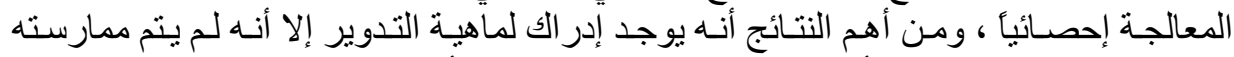

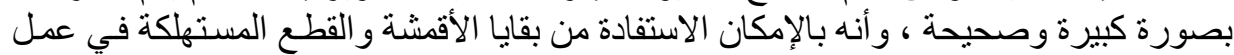

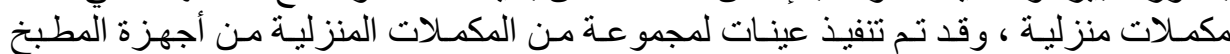

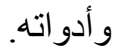

ـ در اسة (آيات بنت عدنان بن عطوة (2012) بعنوان: " الاستفادة من الإمكانات التشكيلية

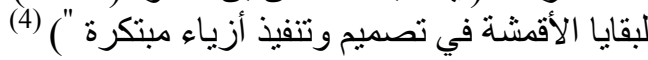

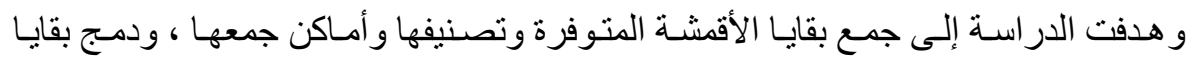

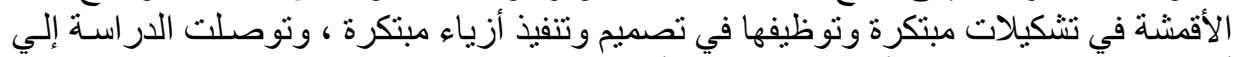

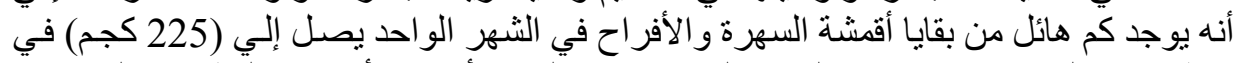

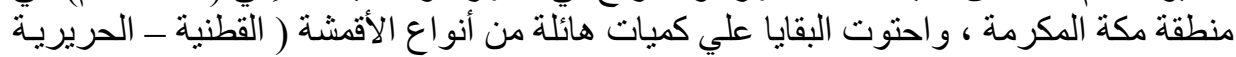

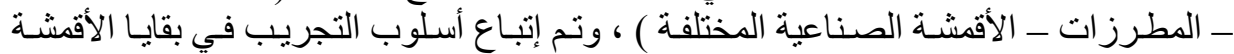

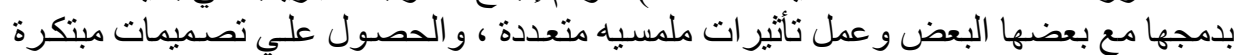

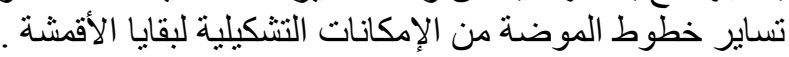

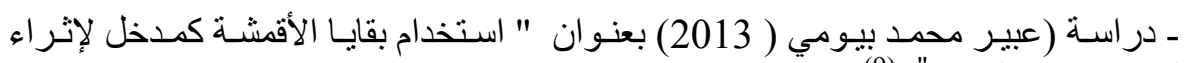

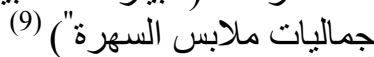

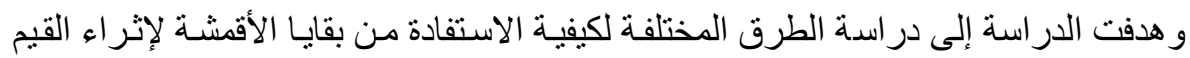

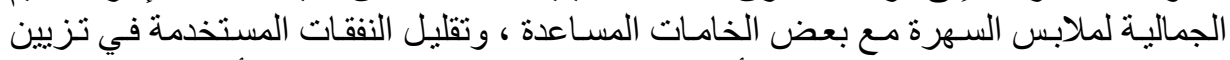

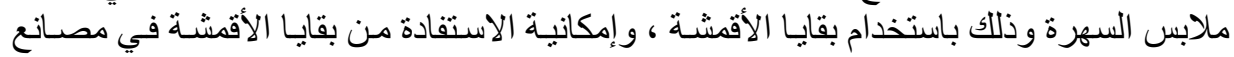

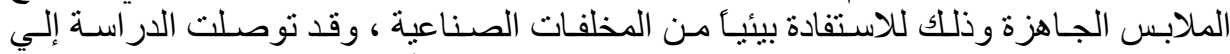

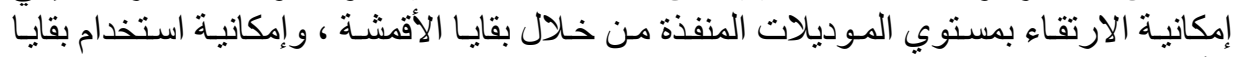

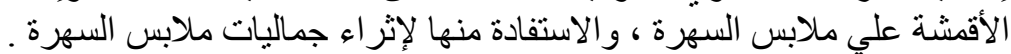

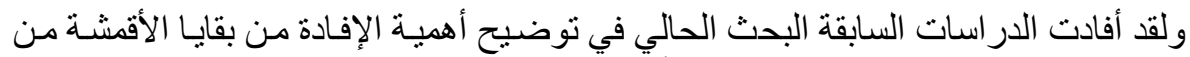

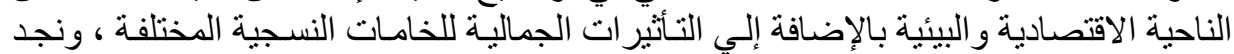

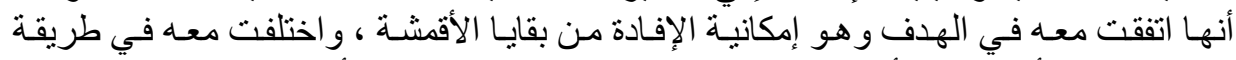

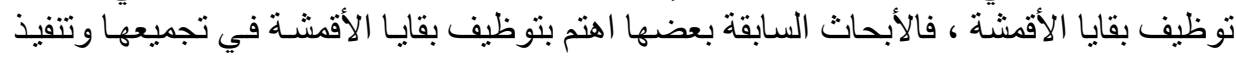




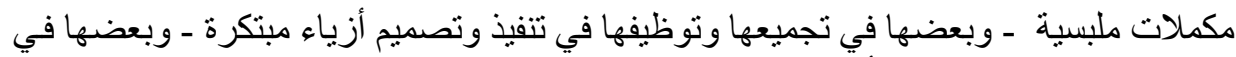

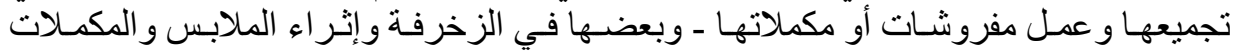

أما البحث الحالي فيهتم بتطبيق أسلوب تقني جديد لتوظيف بقايا الأقمشة ، و هو استغلالها في

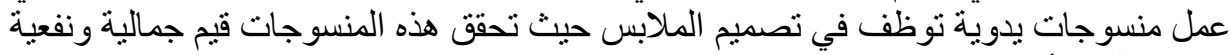

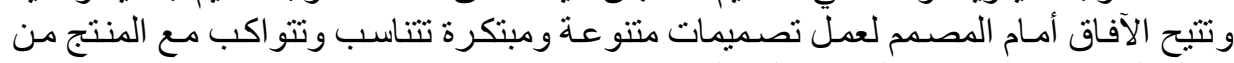

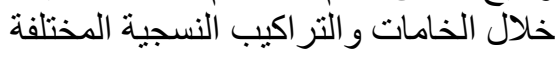

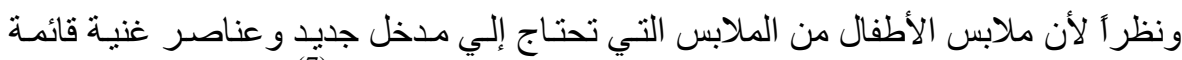

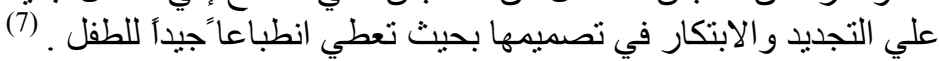

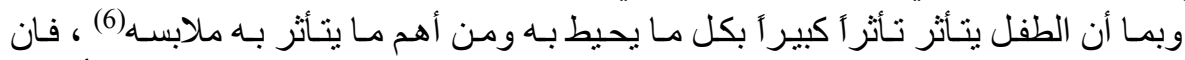

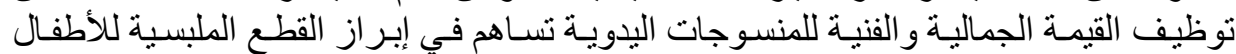

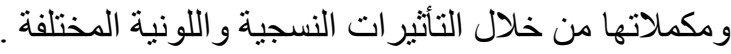

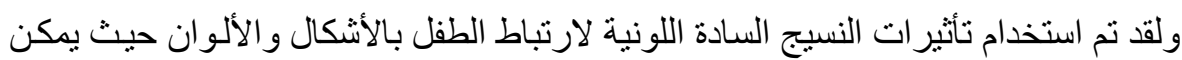

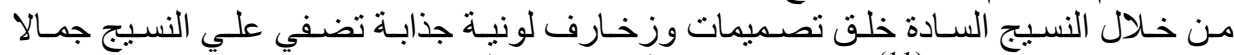

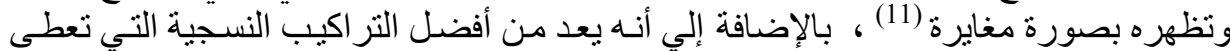

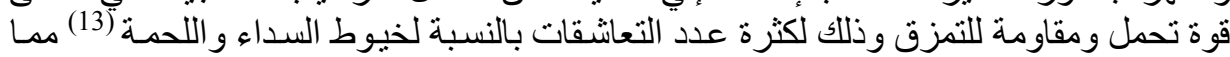

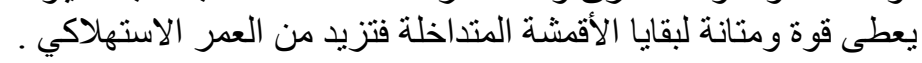

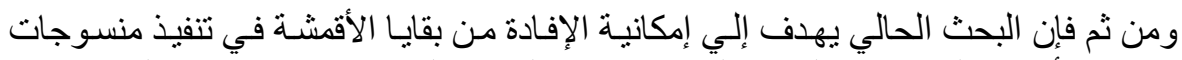

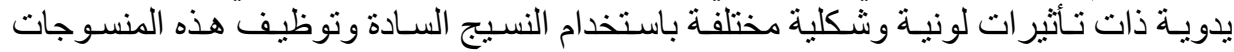
اليدوية ذات القيمة الجمالية في إثراء ملابس الطفة الطفل ومكملاتها .

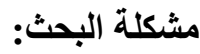

حيث أن العالم يتجه إلي تقليص وتقليل نسب العو ادم وبقايا الأقمشة إلي أقصي درجة مدكنة

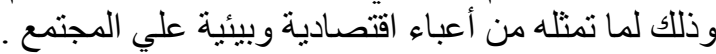

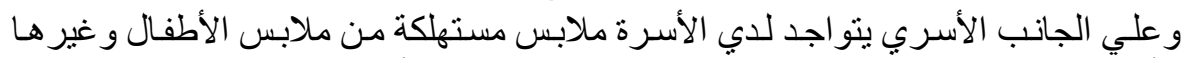

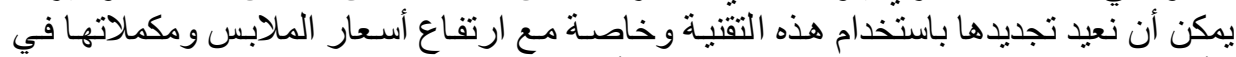

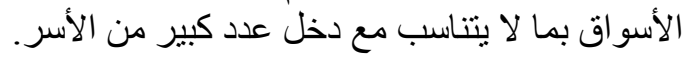

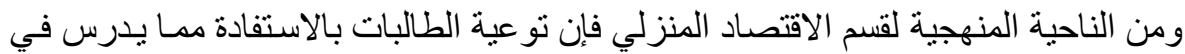

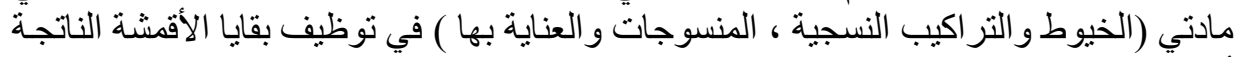

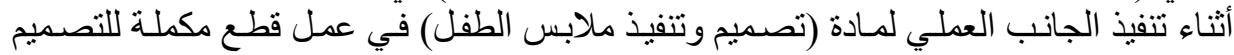

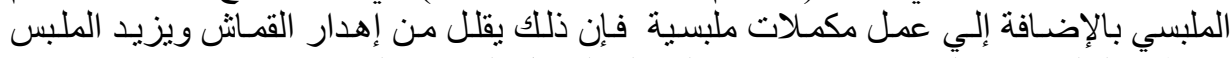

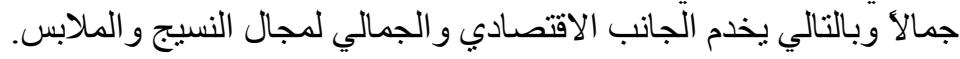

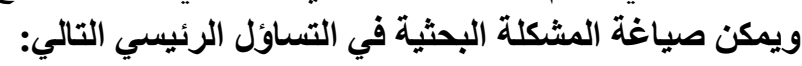
ما إمكانية الإفادة من بقايا بعض الأقمشة باستخدام النسيج اليدوي في إثر اء ملابس الطفل

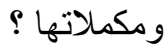


ويتفرع من هذا التساؤل الرئيسي التساؤلات الفرعية التالية :

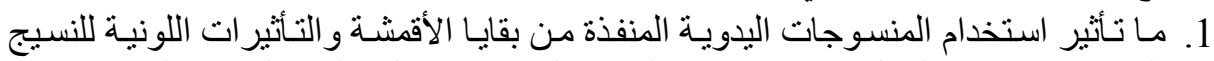

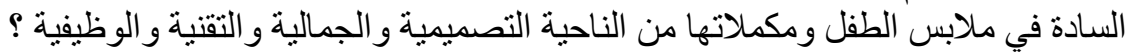
2. ما الفروق بين محاور التقبيم الأربعـة (تصميمية - جمالية - وظيفية النية ـ تقنية) للموديلات ومكملاتها؟

3. ما درجة قبول ملابس الطفل ومكملاتها المستخدم فيها المنسوجات اليدويـة المنفذة من بقايا

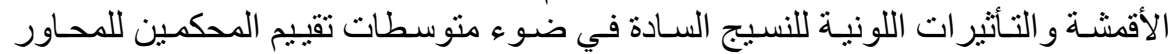
ككل

4. ما درجة قبول ملابس الطفل ومكملاتها المستخدم فيها المنسوجات اليدويـة المنفذة من بقايـا

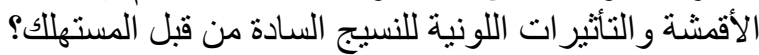

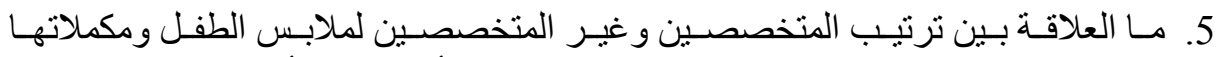

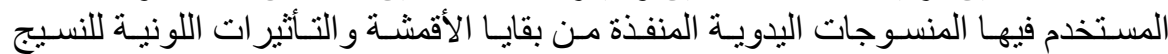
السادة .

\section{تكمن أهمية البحث في النقاط التالية :}

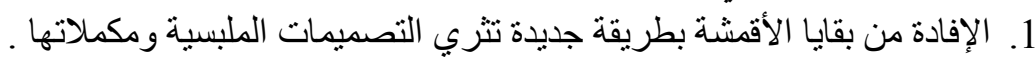

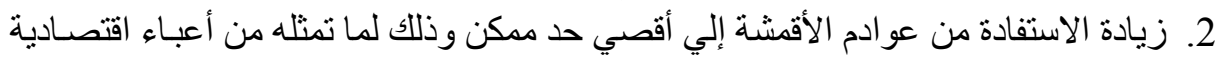

$$
\text { وبيئية علي المجتمع . }
$$

3. المساهمة في تقديم منتجات ملبسية أكثر اقتصادية وذات قيمة جمالية المانية.

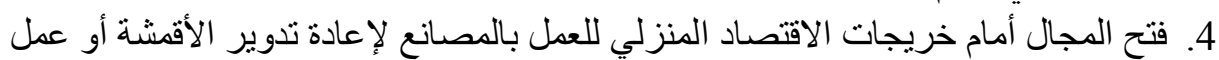

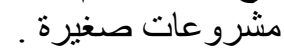

5. الإفادة من الملابس المستهلكة لدي الأسر بتجديدها بهذه الطريقة بما يعود بالنفع علي دخل

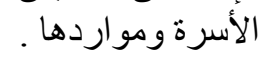

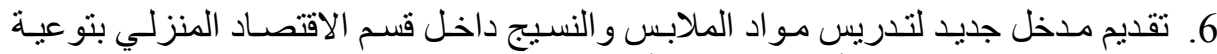

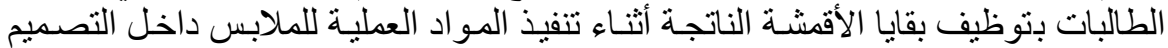

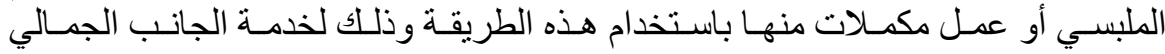
و الاقتصادي للملبس. 7. الربط بين المـواد التـي يتم تدريسـها و الاحتياجـات الفعليـة للمجتمع بمـا يعد بـالنفع علي

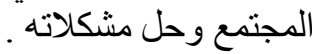

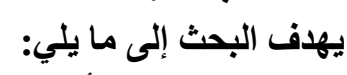

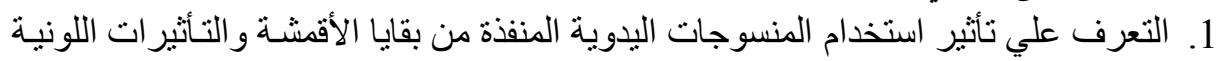

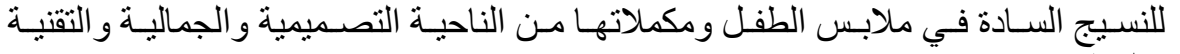


2. در اســة الفـروق بـين محساور التقيـم الأربعـة (تصـيمية - جماليـة - وظبفيـة ـ تقنيـة) للموديلات ومكملاتها .

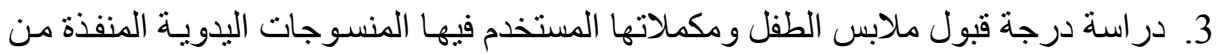

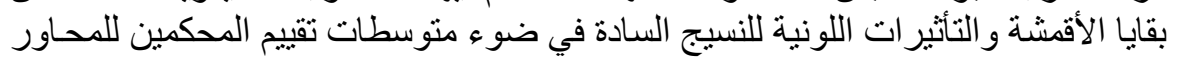
ككل.

4. در اسة درجة قبول ملابس الطفل ومكملاتها المستخدم فيها المنسوجات اليدويـة المنفذة من

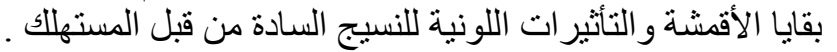

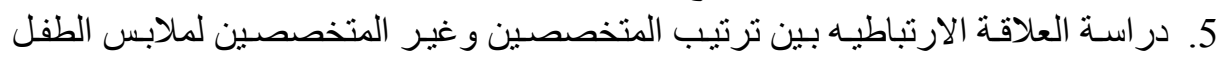

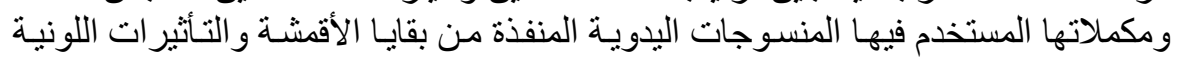
للنسيج السادة .

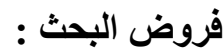

1. توجد علاقة ذات دلالة إحصائية بين استخدام المنسوجات اليدويـة المنفذة من بقايـا الأقمشـة

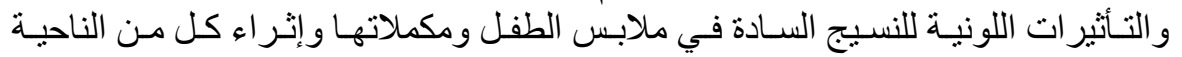
التصميمية و الجمالية و التقنية و الوظيفية.

2. نوجد فروق ذات دلالة إحصائية بين منوسطات محاور التقييم الأربعة (تصميمية - جمالية - وظيفية - تقنية) للموديلات و مكملاتها.

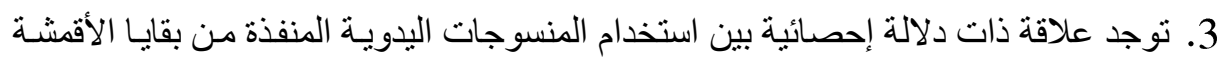

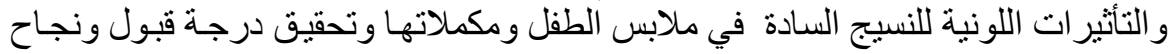

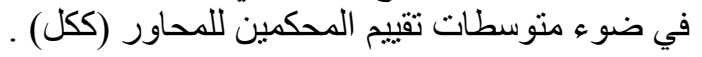

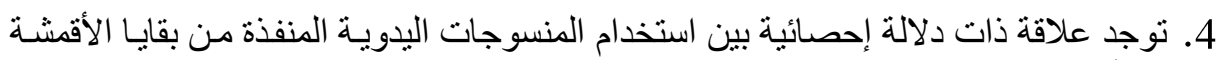
و التأثير ات اللونية للنسيج السادة ودرجة قبول ملابس الطفل ومكملاتها من قبل المستهلك.

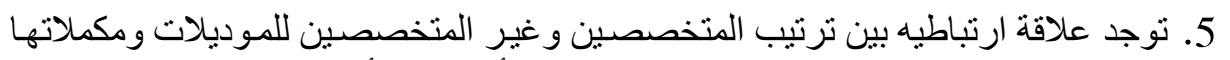

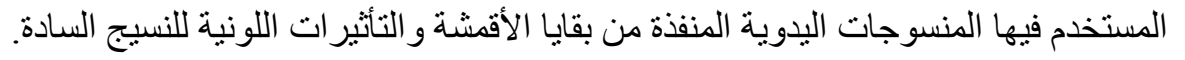

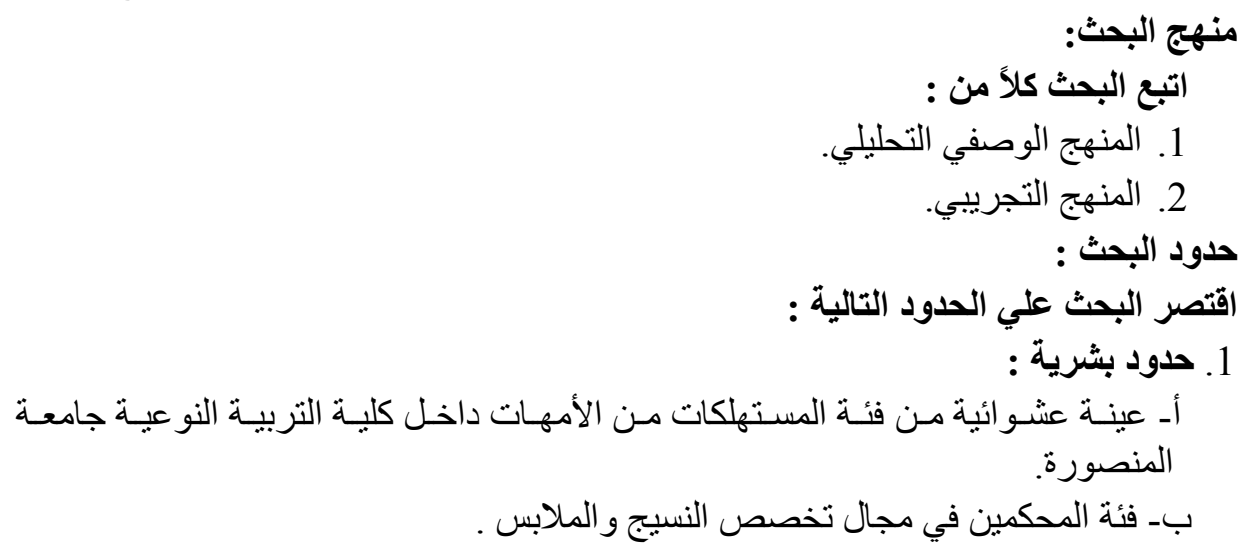


عدد (9) موديلات من ملابس الأطفال الإناث ومكملاتها ( حقيبة ، توكة ، سلسلة ، خاتم ) ،

$$
\text { وقد اقتصرت في تنفيذها علي : مابن }
$$

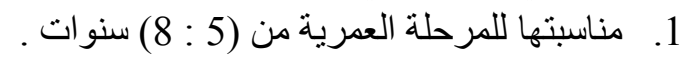

2.

3. استخدام بقايا الأقمشة من خامة ( السنجل جرسيه ليكر ا ) ) .

أدوات البحث :

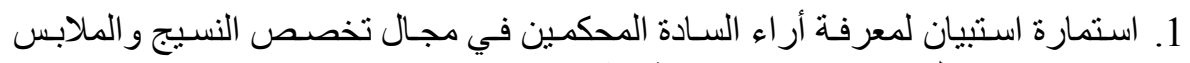

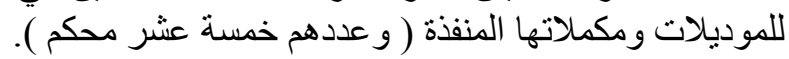

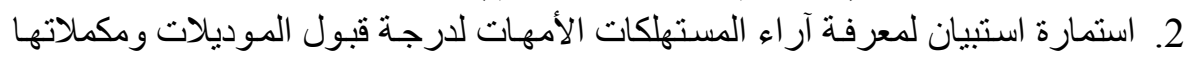

المنفذة ( و عددهن خمسون مستهلكة) . مصطلحات البحث :

1.بقايا الأقمشة :

يقصد بها القطع و الفضلات المتبقية من الأقمشة بأنو اعها المختلفة مثنل القصاصـات الناتجـة

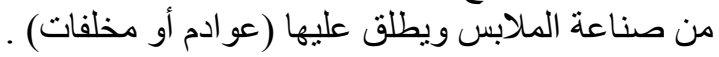

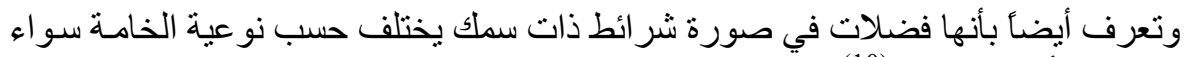

كانت طبيعية أو صناعية .

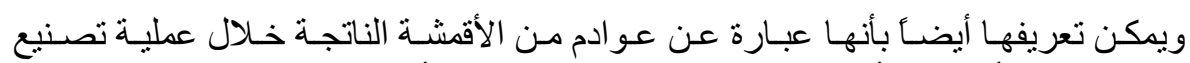

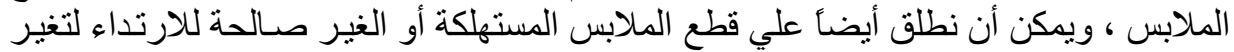

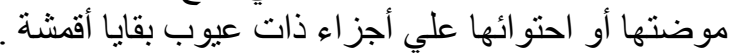

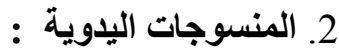

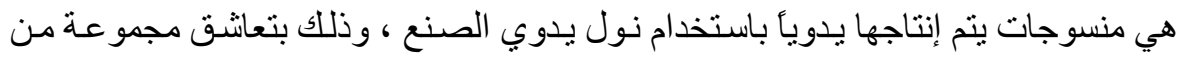

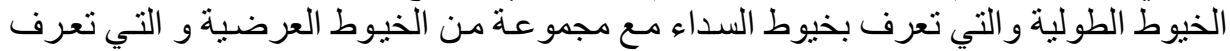

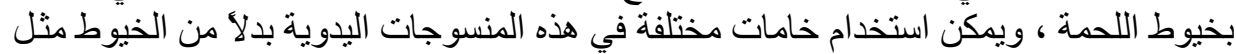

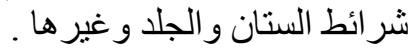

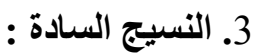

يعتبر النسيج السادة من أبسط أنواع الأنسجة ، ويؤكد أبسط أثنكال التشـابك لمجمو عتين من فن فئن

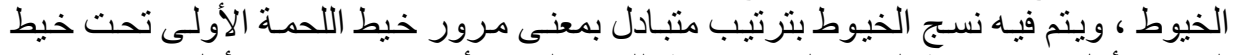

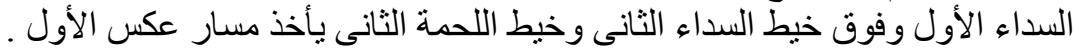

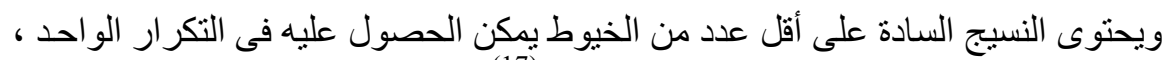

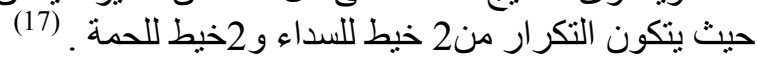




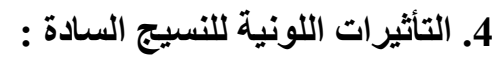

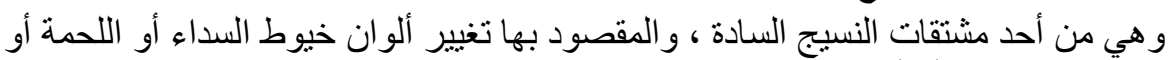

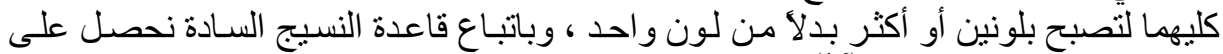

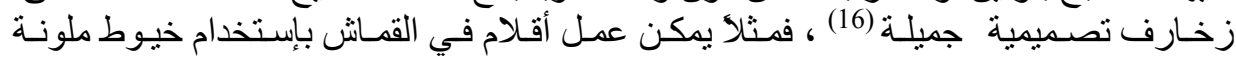

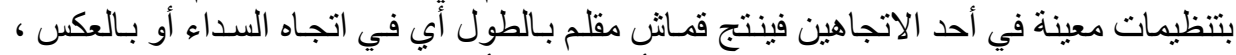

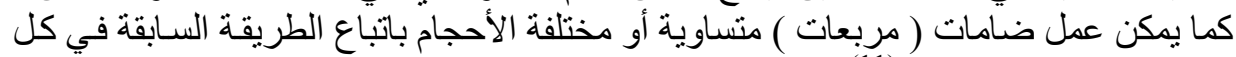

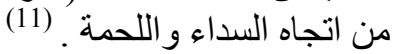

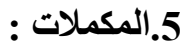

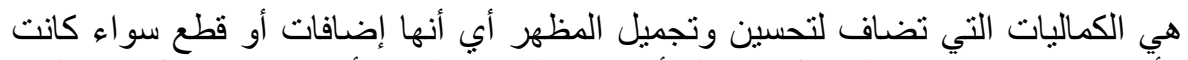

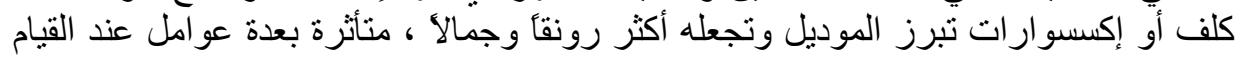

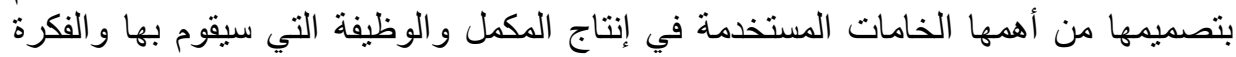

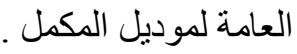

\section{وتنقسم مكملات الملابس إلي :}

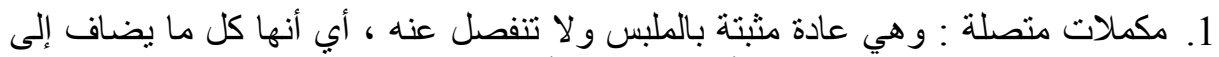

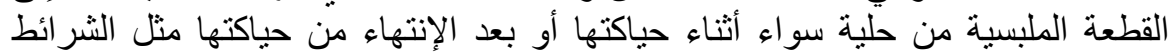

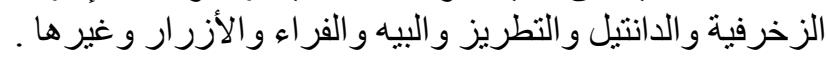

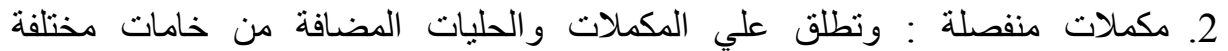

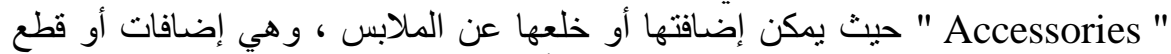

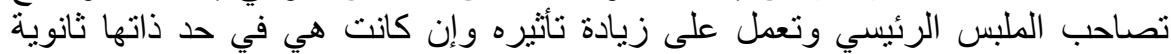

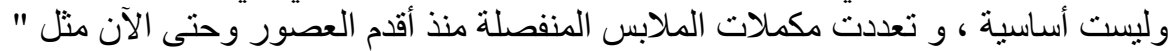

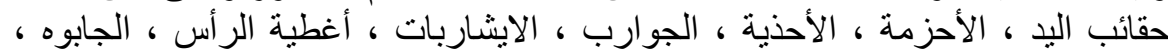

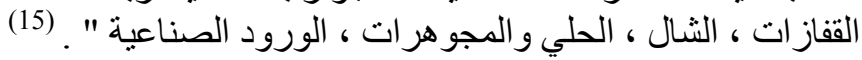

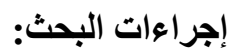

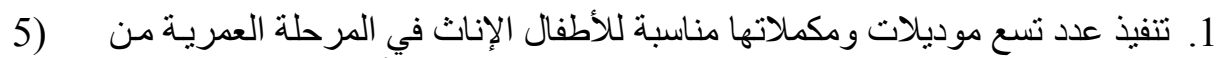

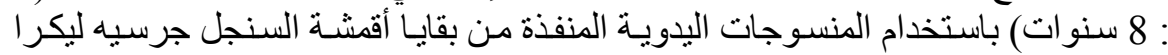

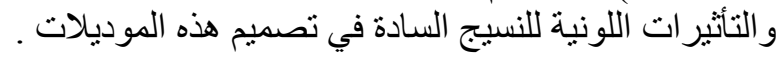

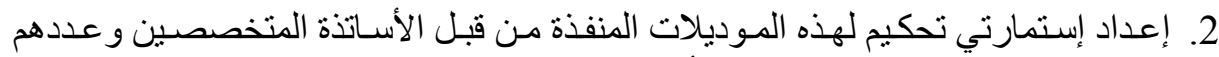

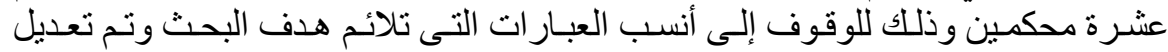

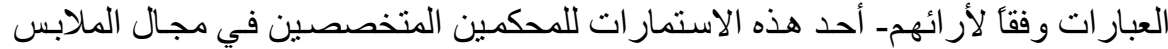

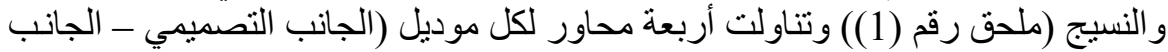

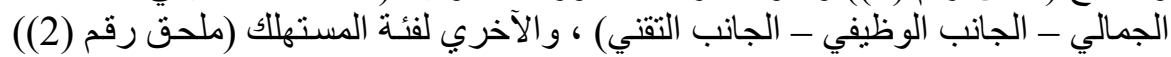
وتناولت ثلاثة عشر بندأ 3. عرض إستمارة التحكيم ( ملحق رقم (1) ) علي السادة المحكمين المتخصصين في مجال

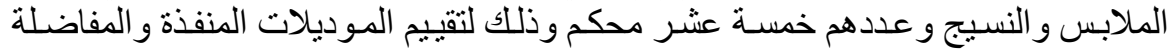

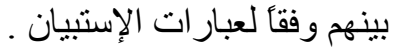




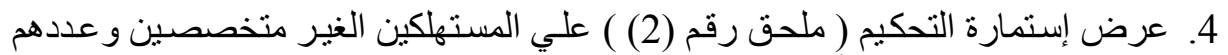

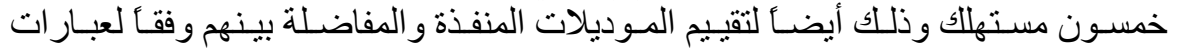

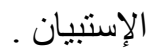
5. استخدام أسلوب التحليل الإحصائى المناسب لمناقثة الفروض و النتائج .

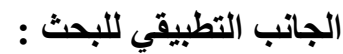

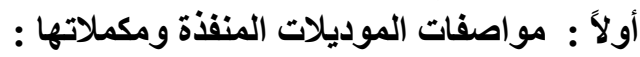

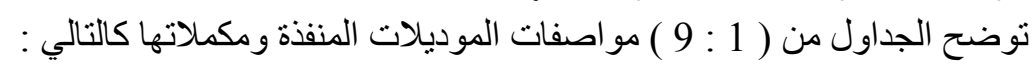
جدول (1) يوضح توصيف الموديل رقم (1) ومكملاته

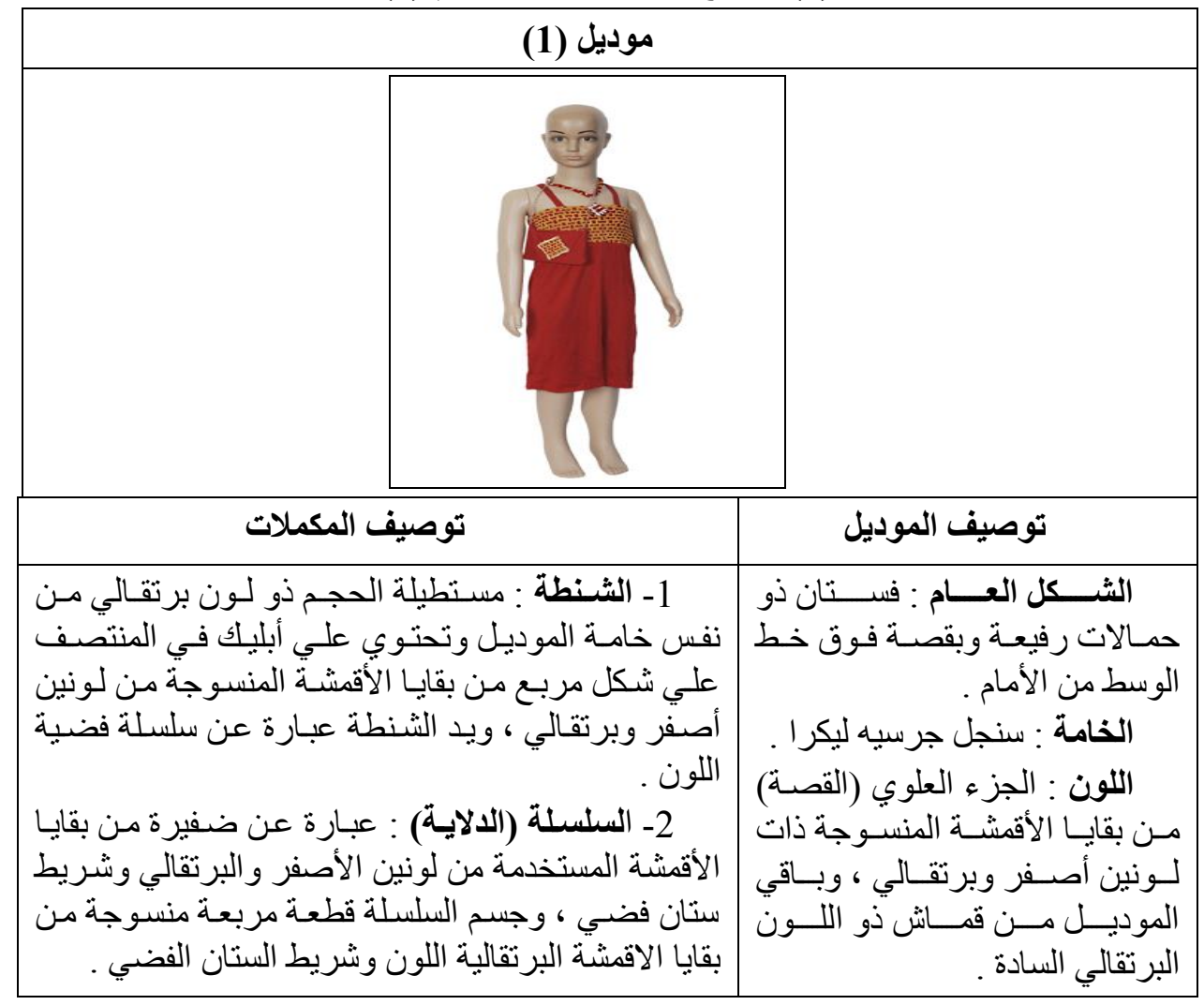




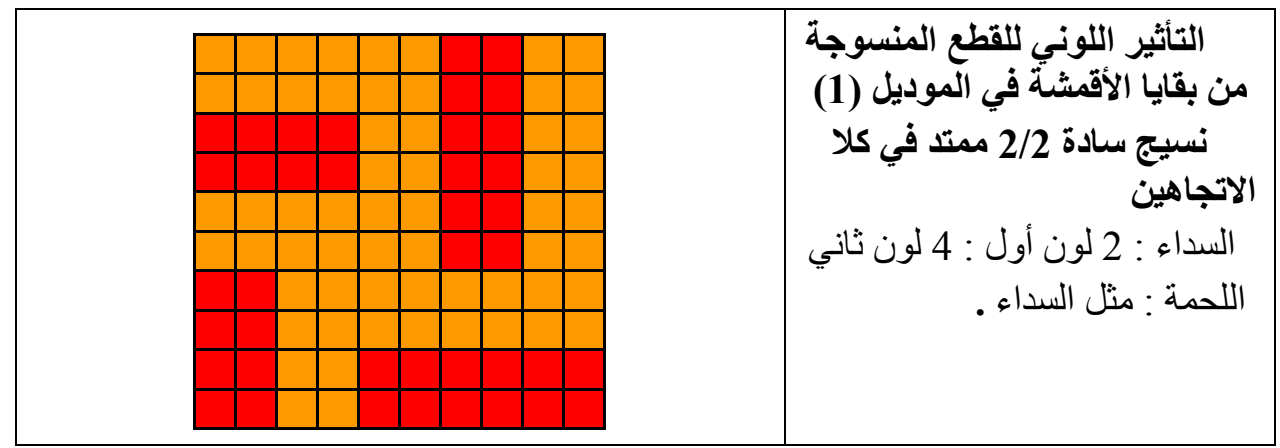

جدول (2) يوضح توصيف الموديل رقم (2) ومكملاته

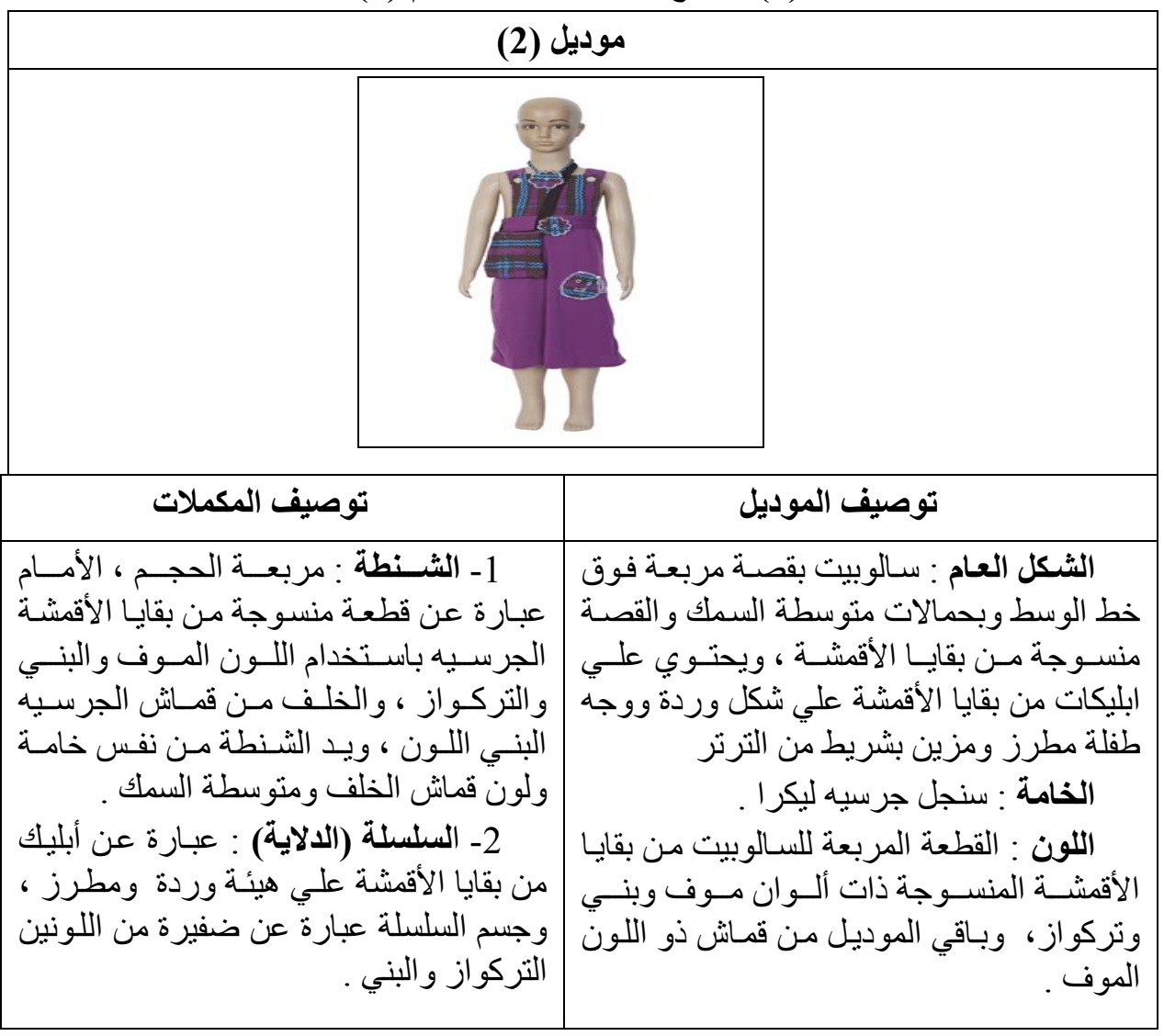




\begin{tabular}{|r|r|l|l|l|l|l|l|l|}
\hline & & & & & & & & \\
\hline
\end{tabular}

جدول (3) يوضح توصيف الموديل رقم (3) ومكملاته

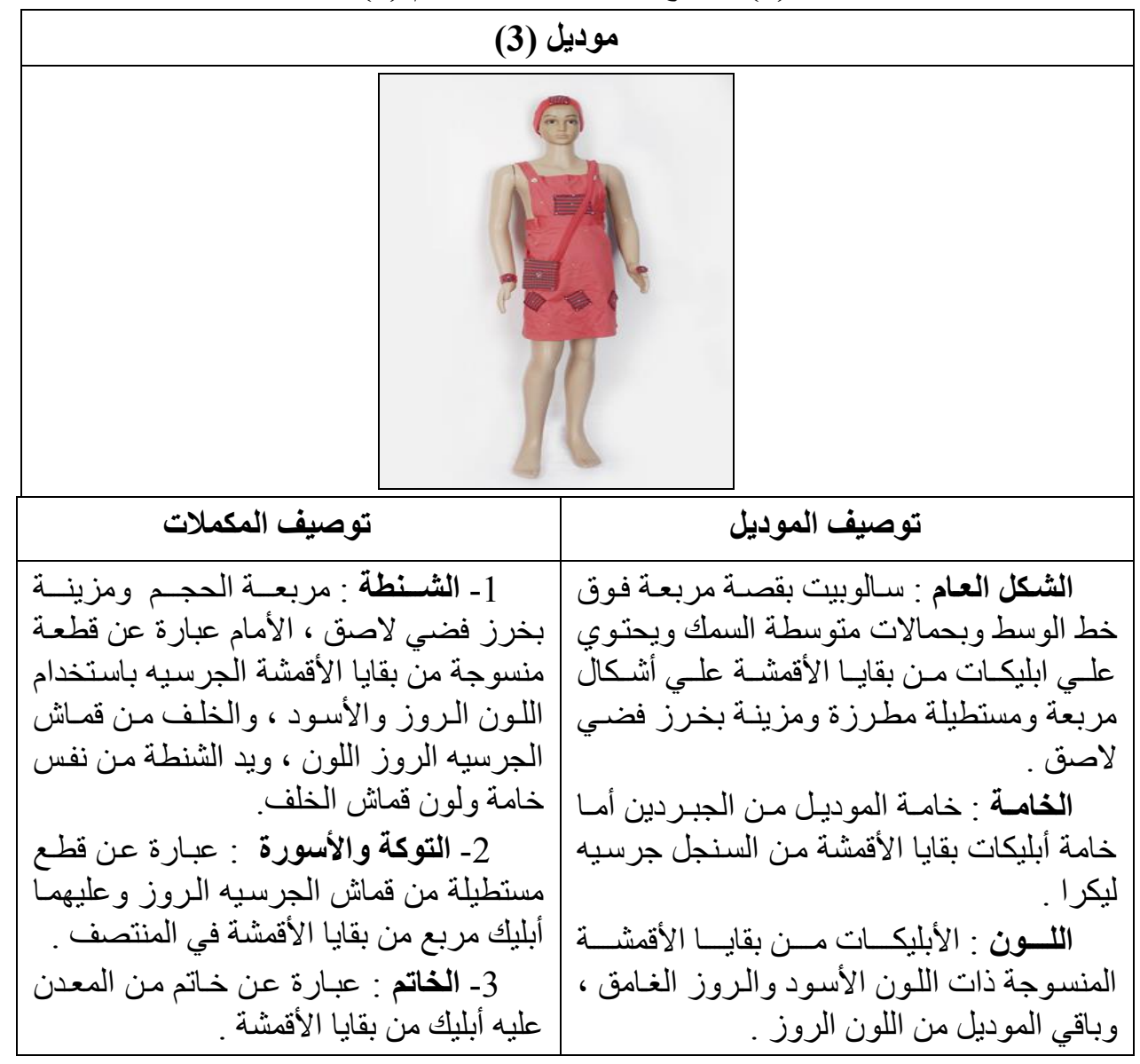




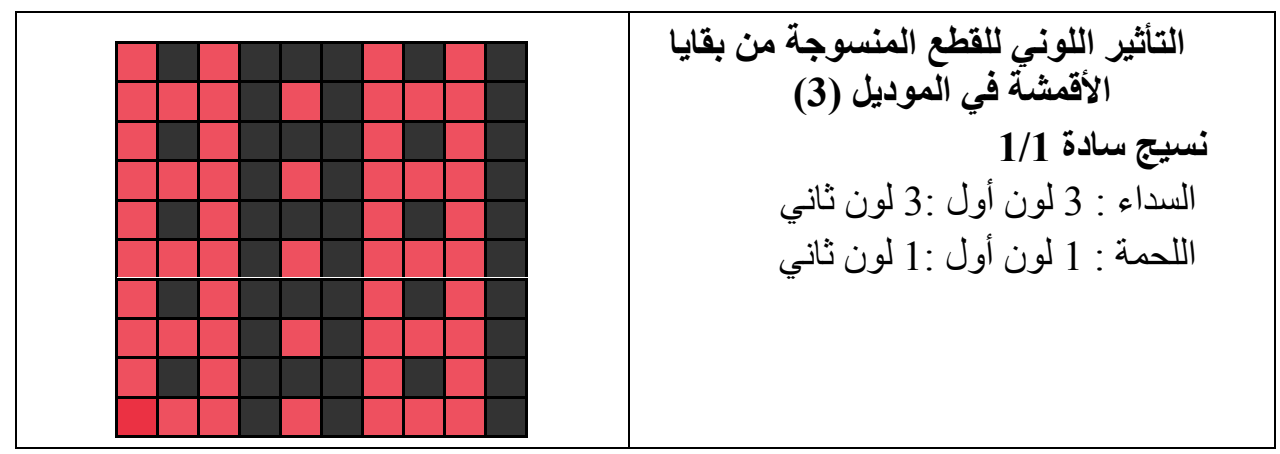

جدول (4) يوضح توصيف الموديل رقم (4) ومكملاته

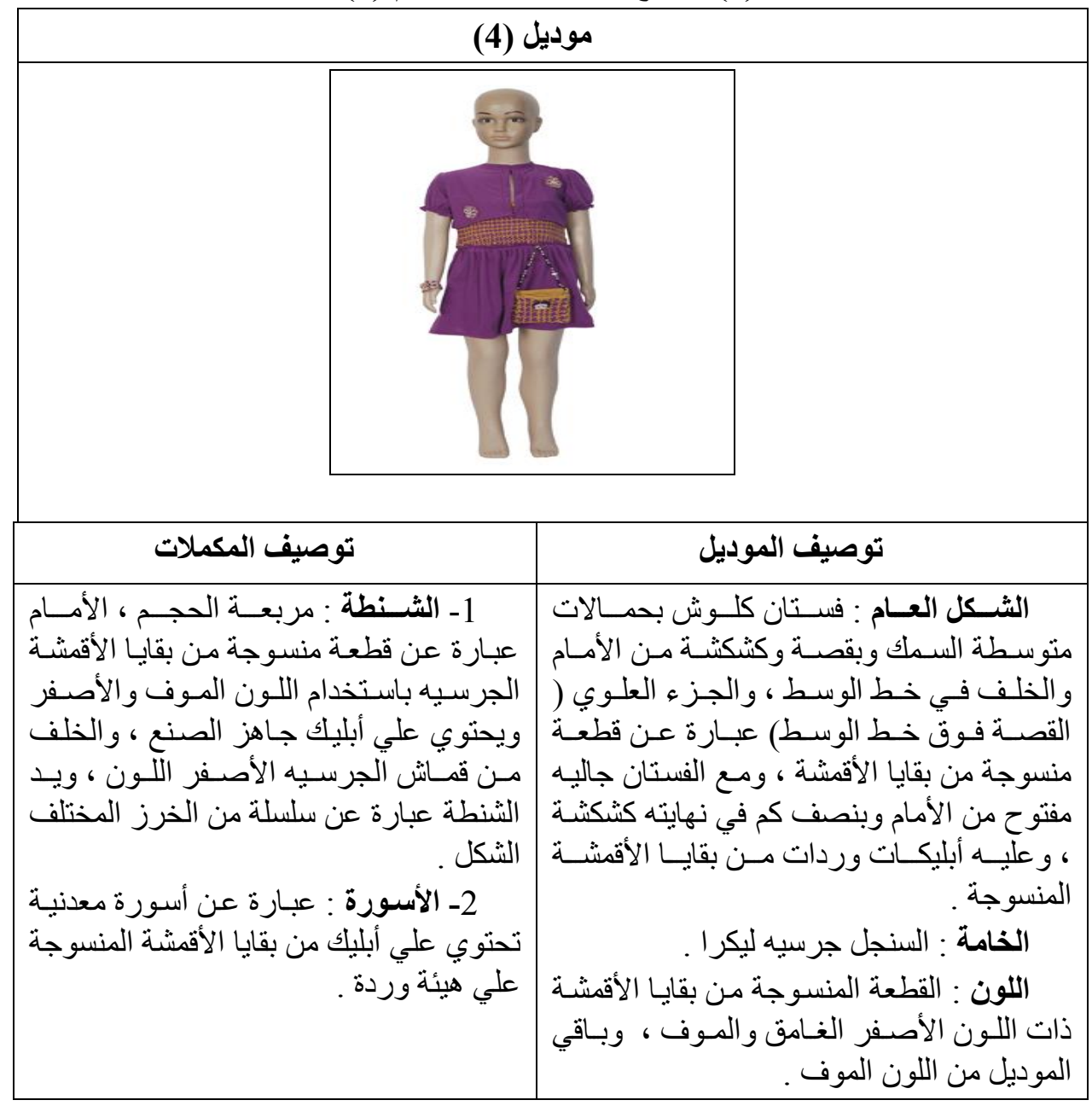




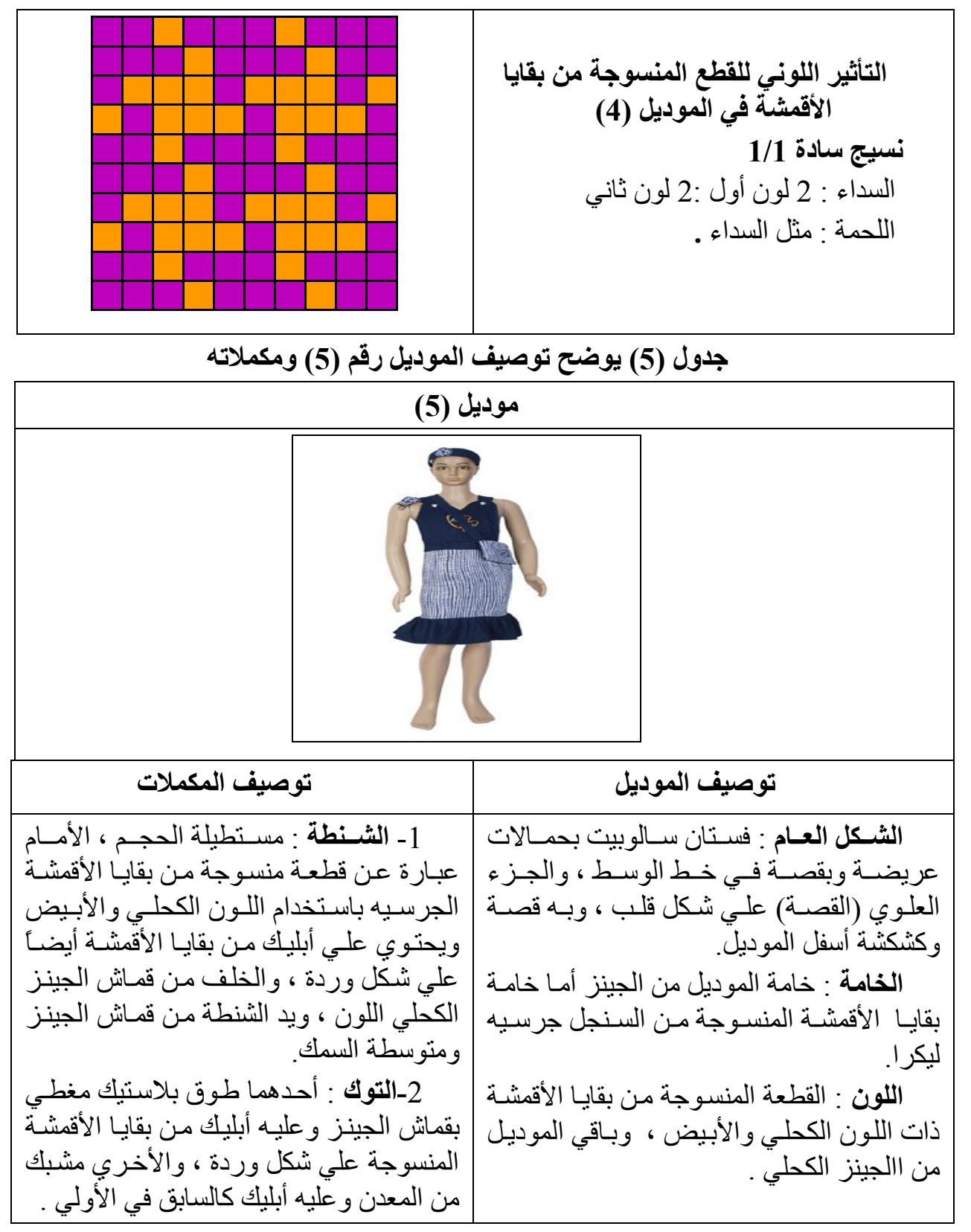




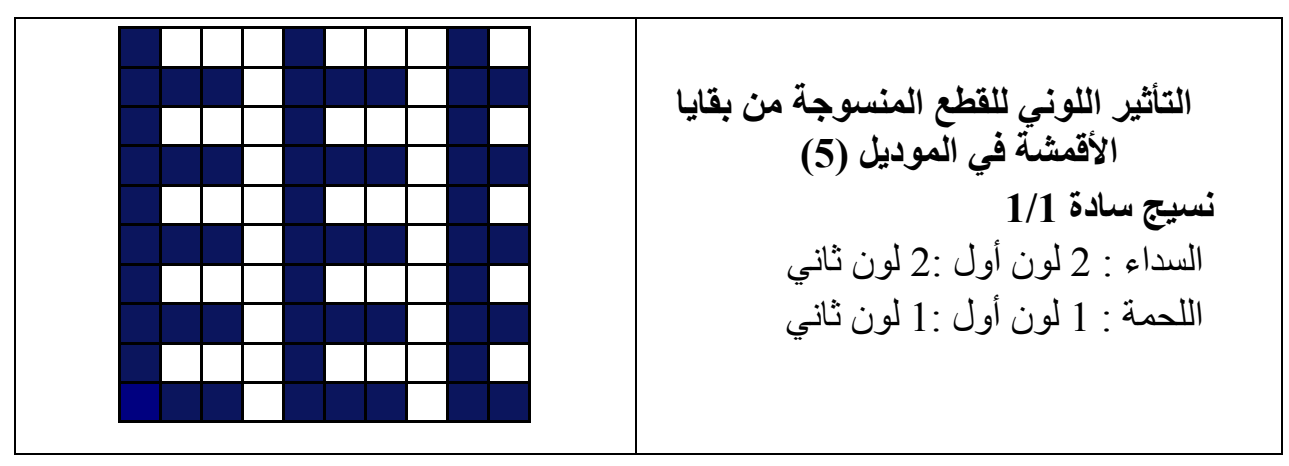

جدول (6) يوضح توصيف الموديل رقم (6) ومكملاته

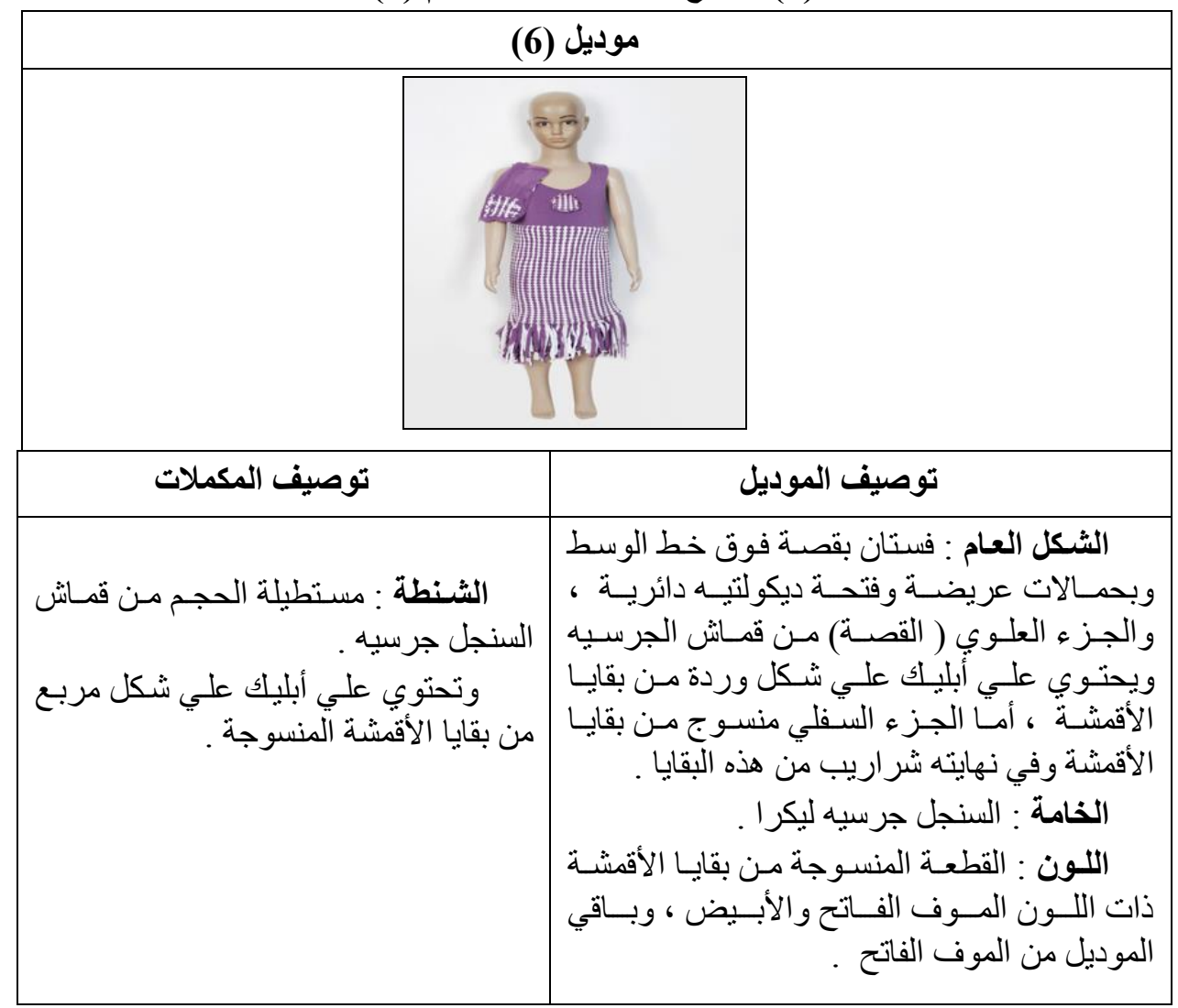




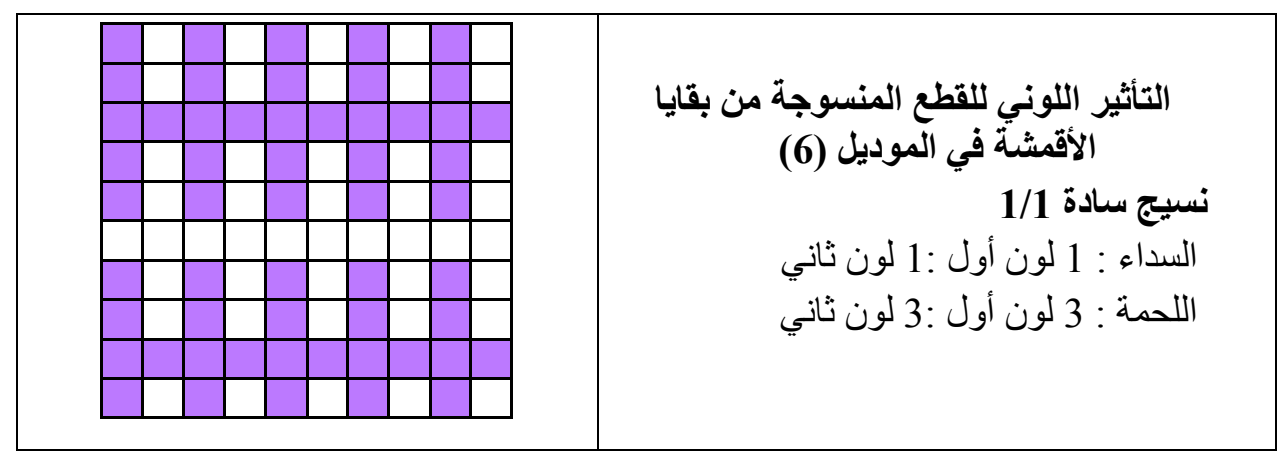

جدول (7) يوضح توصيف الموديل رقم (7) ومكملاته

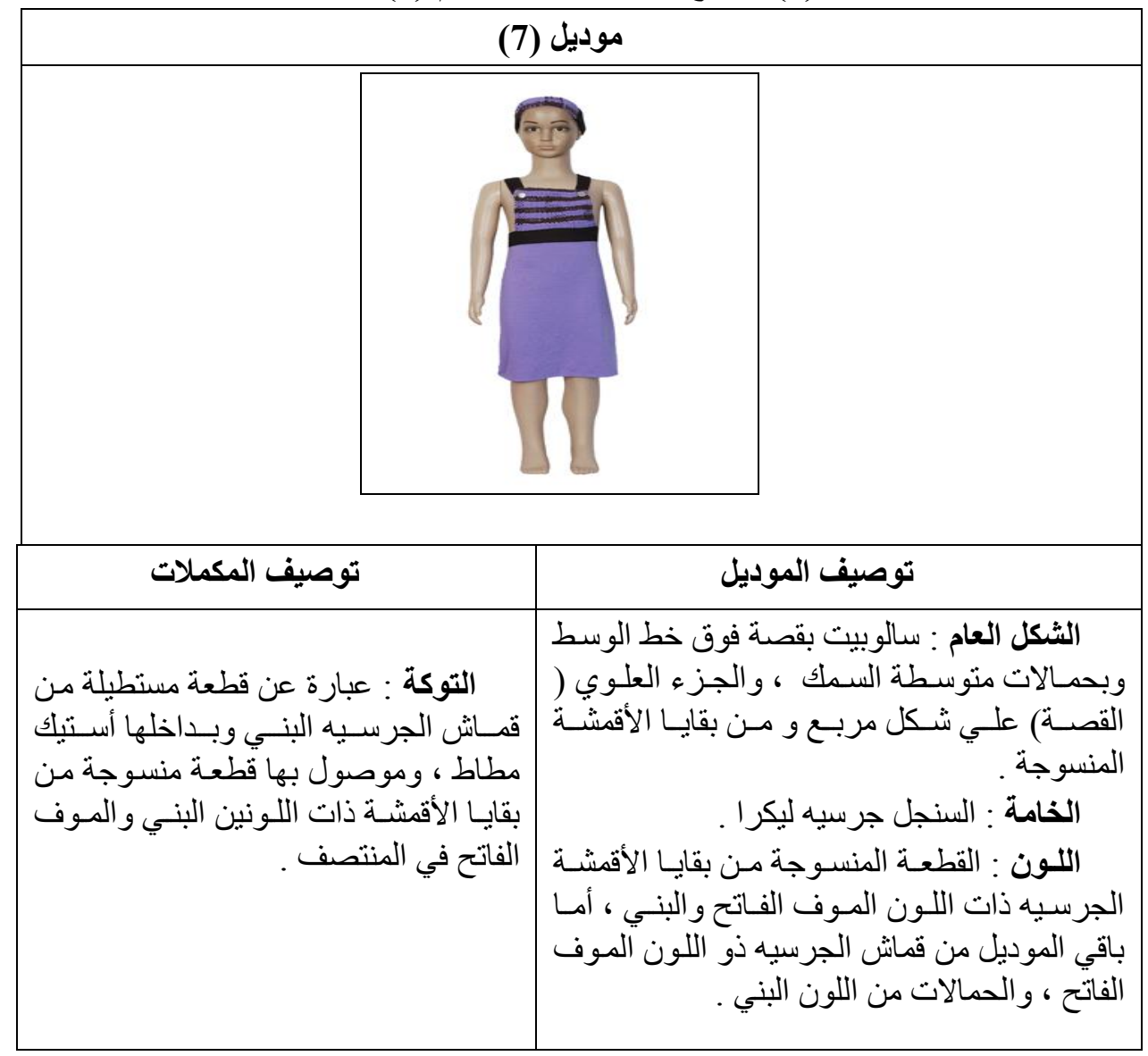




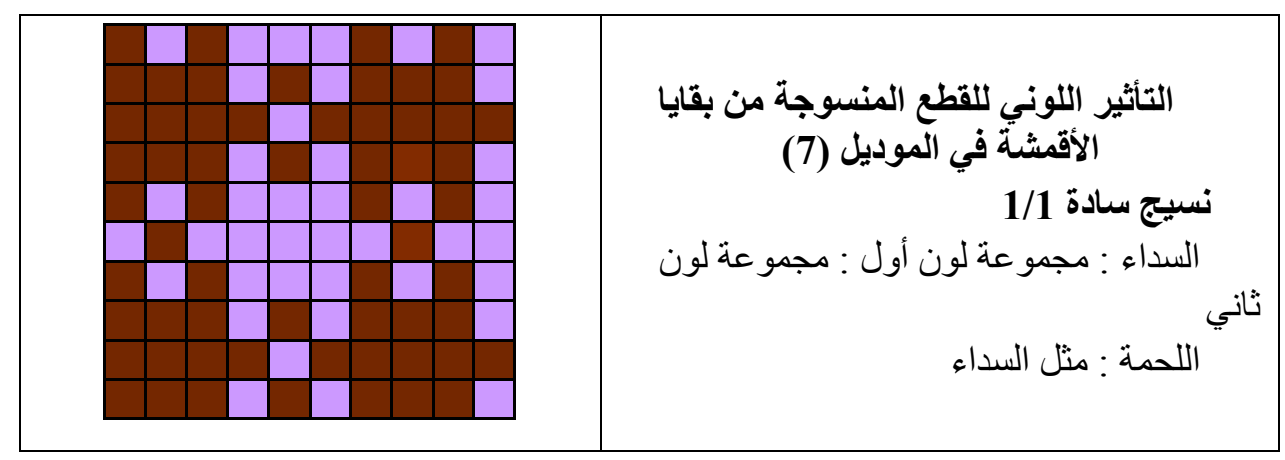

جدول (8) يوضح توصيف الموديل رقم (8) ومكملاته

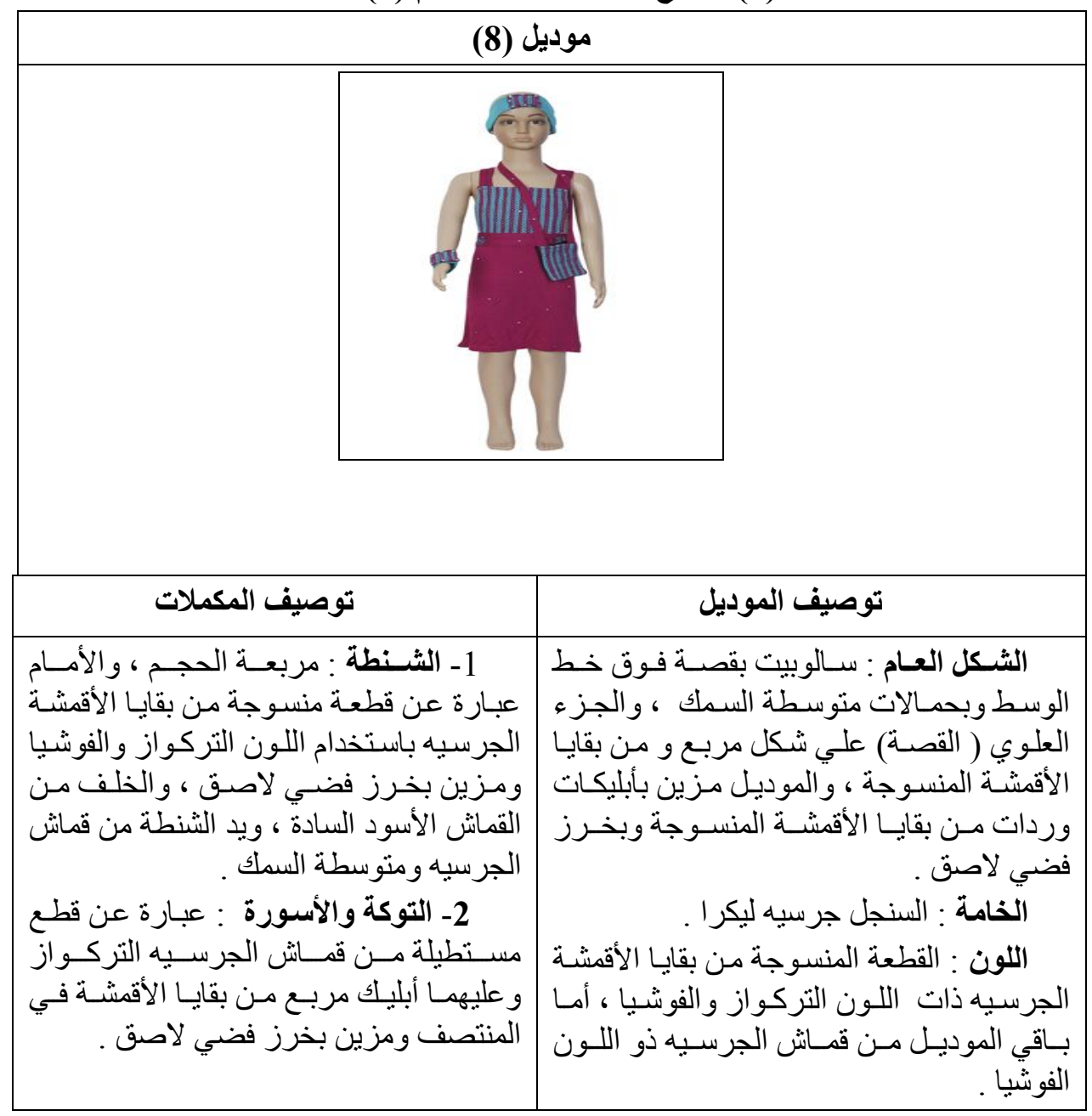




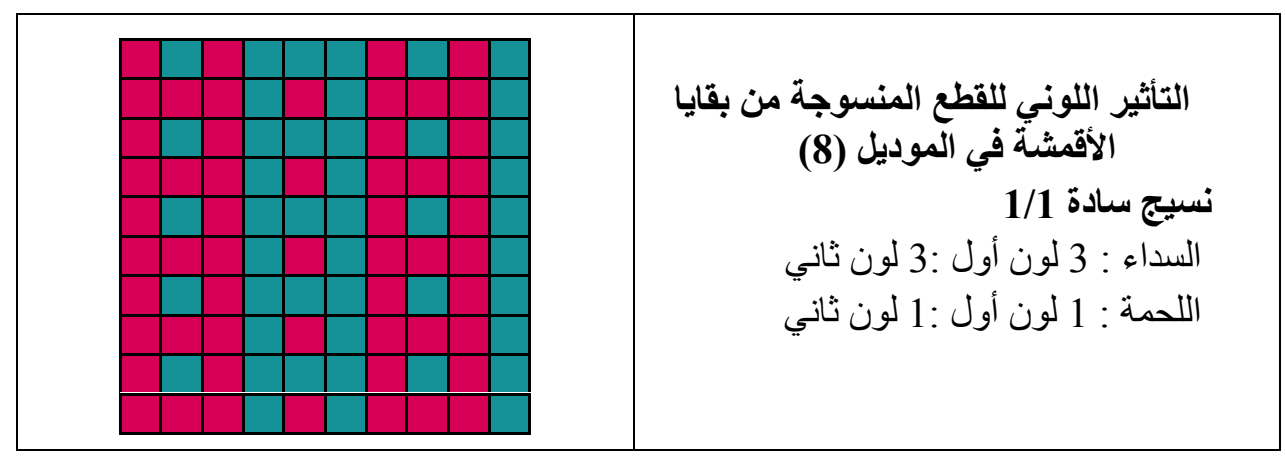

جدول (9) يوضح توصيف الموديل رقم (9) ومكملاته

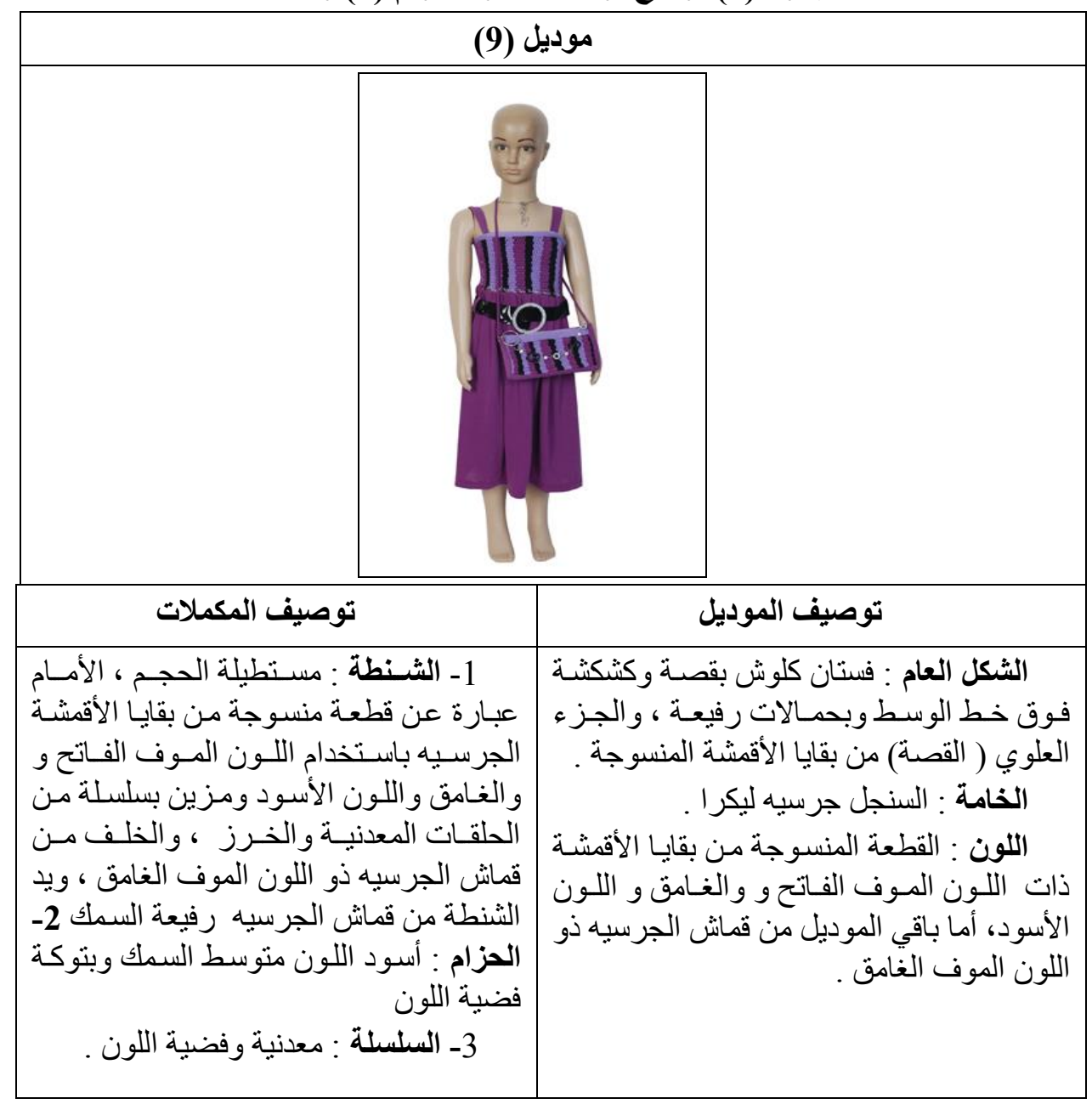




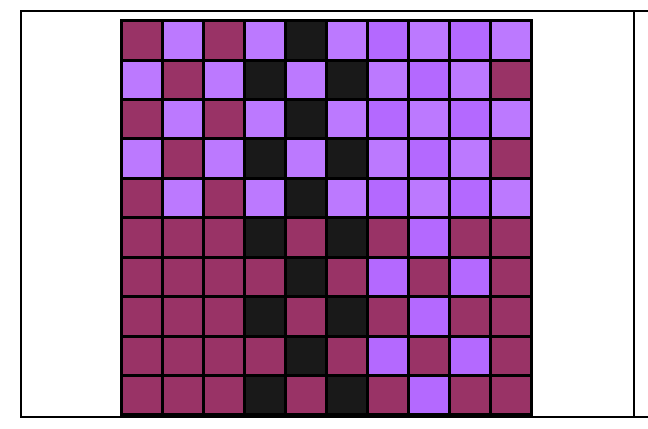

التأثير اللوني للقطع المنسوجة من بقايا

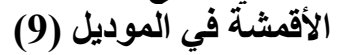

نسيج سادة 1/1

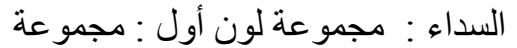

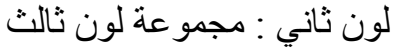

اللحمة : مجمو عة لون لون نأول : مجمو عة لون

ثاني

ثانياً : قياس صدق وثبات اسنمارات التقييم :

1. استمارة تقييم الموديلات المنفذة ومكملاتها وفقاً لآراء المتخصصين :

اختبار صدق محتوي الاستبيان :

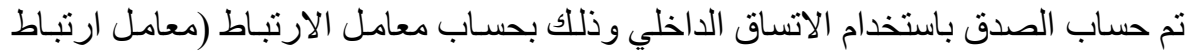

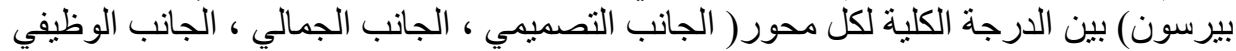

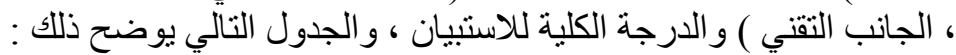

جدول (10) يوضح معاملات الارتباط بين درجة كل محور ودرجة الاستبيان

\begin{tabular}{|c|c|c|}
\hline الدلالة & معامل ارتباط بيرسون & المحور \\
\hline 0.01 & $* * 0.862$ & الجاتب التصميمي \\
\hline 0.01 & $* * 0.740$ & الجاتب الجمالي \\
\hline 0.01 & $* * 0.738$ & الجاتب التقني \\
\hline 0.01 & $* * 0.8 .6$ & الجاتب الوظيفي \\
\hline
\end{tabular}

يتضح من الجدول أن معاملات الارتباط كلها دالة عند مستوي (0.01) لاقتر ابها من الو احد

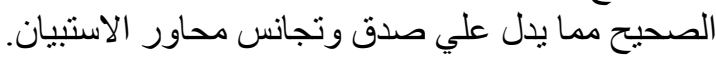

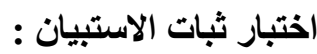

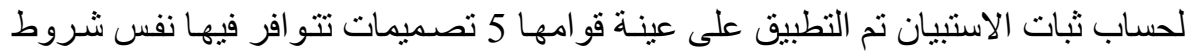
عينة الدر اسة وبعد التطبيق تم حساب الثبات بطريقة التجزئة النصفية Split-Half كالتالي:

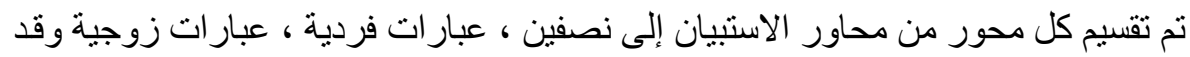

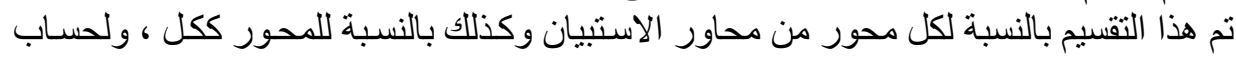

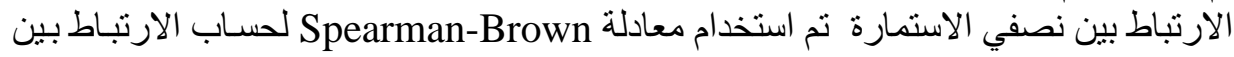

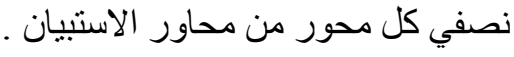


مجلة الاقتصاد المنزلى - مجلد 24 العدد الأول - 2014

جدول (11) يوضح معامل ارتباط التجزئة النصفية لمحاور الاستبيان ككل ومحاوره الفرعية

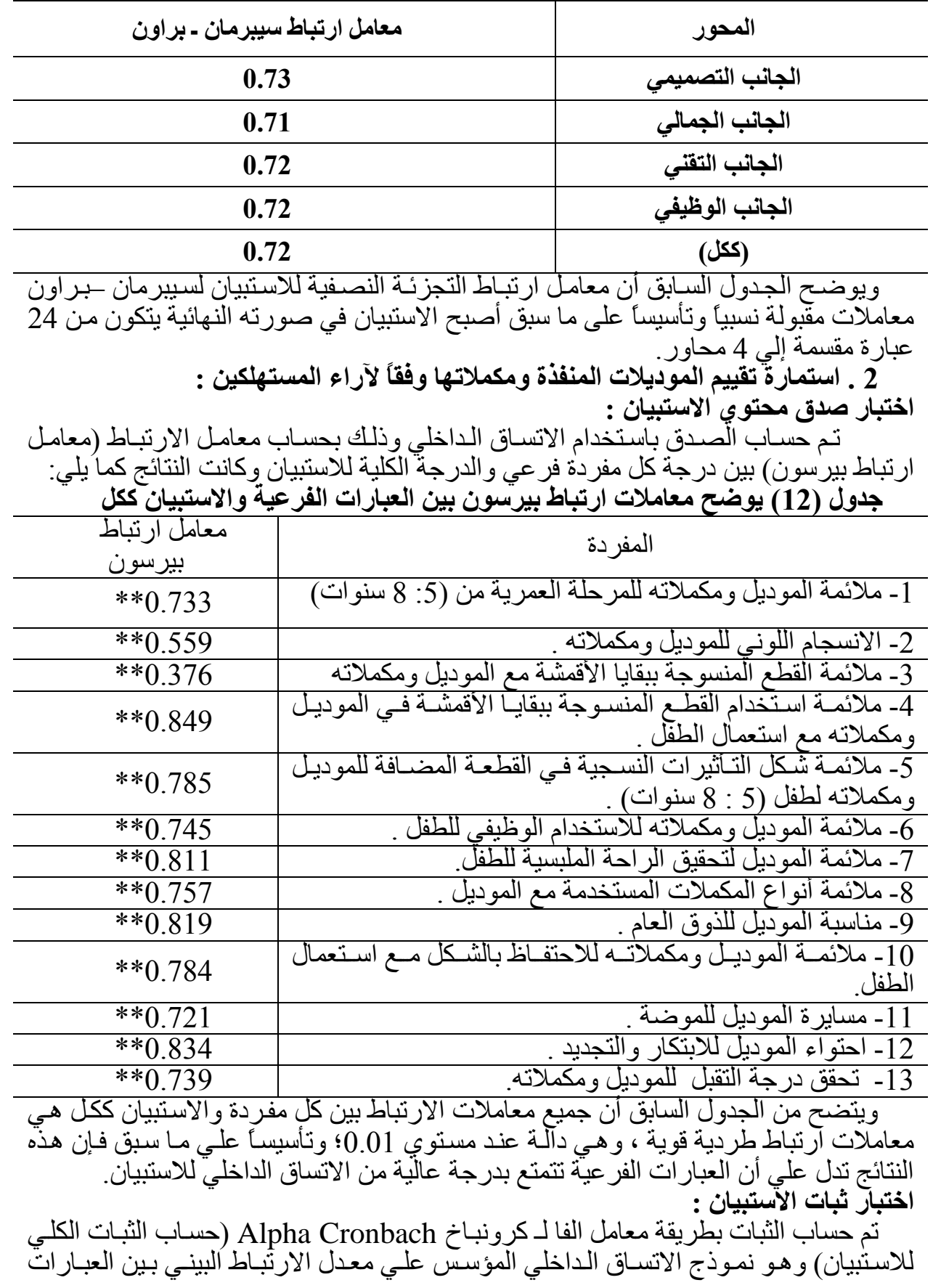


وبلغت قيمته ( 0.87) و هي دالة عند مستوي 0.01 ممـا يؤكد علي أن الاستبيان يتمتع بدرجة. عالية من الثبات فئه

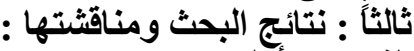

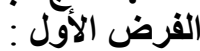

توجد علاقة ذات دلالة إحصائية بين استخدام المنسوجات اليدويـة المنفذة من بقايـا الأقمشـة

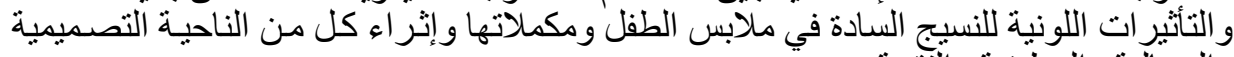

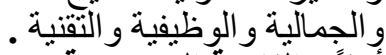

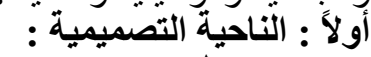
جدول (13) يوضيح متوسطات تقييمات المحكمين للمحور الأول من محاور التقييم

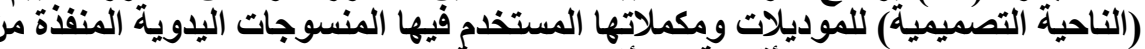

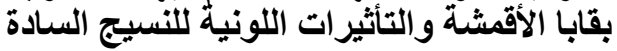

\begin{tabular}{|c|c|c|c|c|c|c|c|c|c|}
\hline الموديل & $\begin{array}{l}\text { الموديل } \\
\text { (8) }\end{array}$ & $\begin{array}{l}\text { (7) الموديل } \\
\text { (7) }\end{array}$ & $\begin{array}{l}\text { الموديل } \\
\text { (6) }\end{array}$ & $\begin{array}{l}\text { (الموديل } \\
\text { ( } 5 \text { ) }\end{array}$ & (الموديل & الموديل & $\begin{array}{l}\text { الموديل } \\
\text { (2) }\end{array}$ & الموديل & الناحية التصميمية الأول \\
\hline 2.0 & 2.0 & 2.0 & 2.0 & 2.0 & 2.0 & 2.0 & 2.0 & 2.0 & 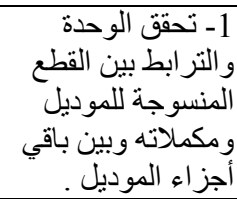 \\
\hline 3.0 & 3.0 & 3.0 & 3.0 & 3.0 & 3.0 & 3.0 & 3.0 & 3.0 & 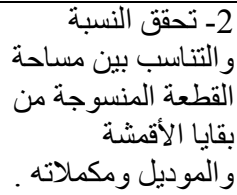 \\
\hline 3.0 & 3.0 & 3.0 & 3.0 & 3.0 & 3.0 & 3.0 & 3.0 & 3.0 & 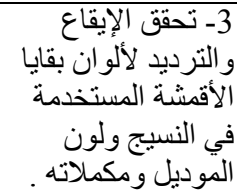 \\
\hline 3.0 & 3.0 & 3.0 & 3.0 & 3.0 & 3.0 & 3.0 & 3.0 & 3.0 & 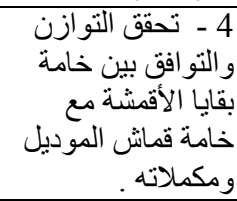 \\
\hline 3.0 & 3.0 & 3.0 & 3.0 & 3.0 & 3.0 & 3.0 & 3.0 & 3.0 & 5- من خلال الدمق الموديل بين \\
\hline 2.1 & 2.1 & 2.1 & 2.1 & 2.1 & 2.1 & 2.1 & 2.1 & 2.1 & 6 - ملائمة تصميم \\
\hline 2.7 & 2.7 & 2.7 & 2.7 & 2.7 & 2.7 & 2.7 & 2.7 & 2.7 & متوكمين تقييمات \\
\hline 89.4 & 89.4 & 89.4 & 89.4 & 89.4 & 89.4 & 89.4 & 89.4 & 89.4 & تلقييم الجودة الكلية \\
\hline
\end{tabular}




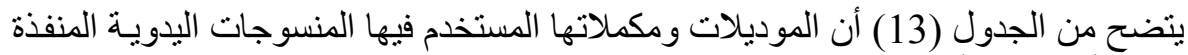

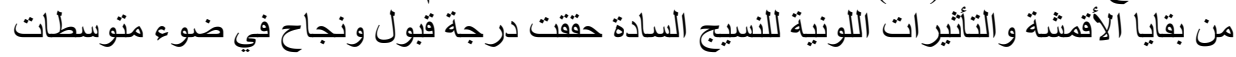

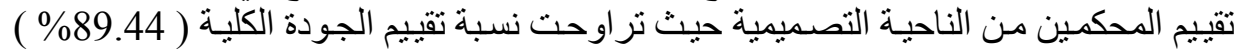

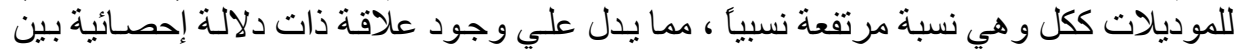

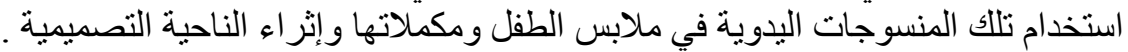

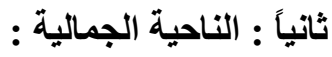
جدول (14) يوضح متوسطات تقييمات المحكمين للمحور الثاني من محاور التقييم

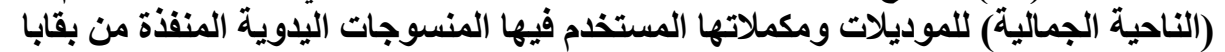
الأقمشة والتأثيرات اللونية للنسيج السادة المنيات

\begin{tabular}{|c|c|c|c|c|c|c|c|c|c|}
\hline $\begin{array}{l}\text { الموديل } \\
\text { (9) }\end{array}$ & $\begin{array}{c}\text { الموديل } \\
\text { (8) }\end{array}$ & $\begin{array}{l}\text { الموديل } \\
\text { (7) }\end{array}$ & $\begin{array}{l}\text { الموديل } \\
\text { (6) }\end{array}$ & الموديل & الموديل & الموديل & $\begin{array}{l}\text { الموديل } \\
\text { (2) }\end{array}$ & $\begin{array}{l}\text { الموديل } \\
\text { (1) }\end{array}$ & الناحية الجمالية الثحور \\
\hline 1.9 & 3.0 & 3.0 & 1.4 & 1.0 & 2.0 & 3.0 & 2.6 & 2.5 & 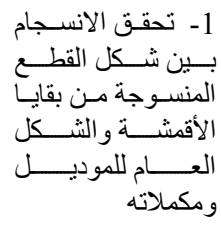 \\
\hline 1.8 & 2.9 & 2.7 & 1.2 & 2.0 & 2.1 & 2.1 & 2.4 & 2.1 & 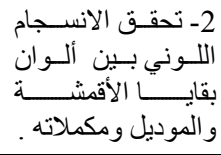 \\
\hline 1.4 & 2.9 & 2.6 & 1.2 & 1.8 & 2.0 & 2.0 & 2.7 & 2.0 & 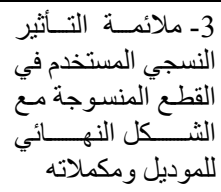 \\
\hline 1.8 & 2.9 & 2.6 & 1.2 & 1.9 & 2.0 & 2.0 & 2.3 & 2.0 & 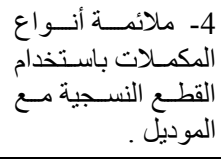 \\
\hline 1.8 & 2.9 & 2.6 & 2.0 & 2.0 & 2.0 & 2.0 & 2.5 & 2.0 & 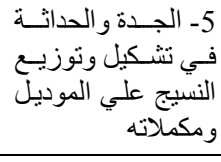 \\
\hline 1.8 & 3.0 & 3.0 & 3.0 & 3.0 & 3.0 & 2.9 & 3.0 & 2.0 & 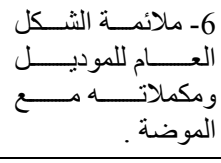 \\
\hline 1.8 & 2.9 & 2.8 & 1.7 & 1.95 & 2.2 & 2.3 & 2.6 & 2.1 & متوسط تقييمات \\
\hline 58.3 & 97.8 & 91.7 & 55.6 & 65.0 & 72.8 & 77.8 & 86.1 & 70.0 & تقييم اللجودة الكلية \\
\hline
\end{tabular}




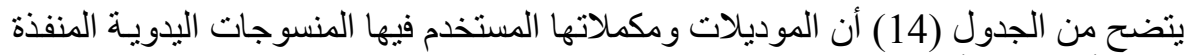

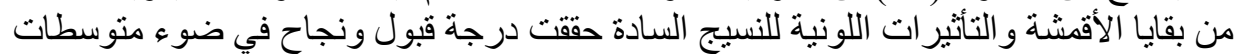

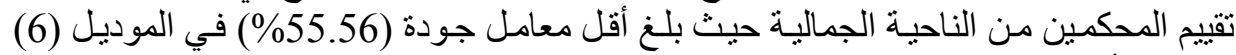

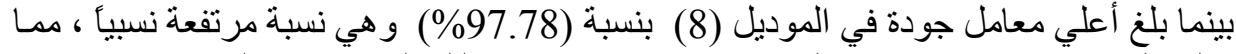

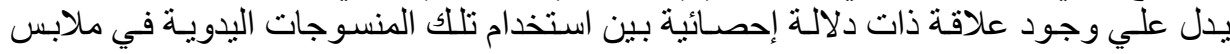
الطفل ومكملاتها و إثر اء الناحية الجمالية .

ثالثاً: الناحية التقنية :

جدول (15) يوضح متوسطات تقييمات المحكمين للمحور الثالث من محاور التقييم (الناحية التقنية) للموديلات ومكملاتها المستخدم فيها المنسوجات اليدوية المنفذة من بقابا

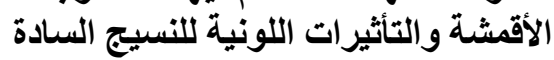

\begin{tabular}{|c|c|c|c|c|c|c|c|c|c|}
\hline $\begin{array}{l}\text { الموديل } \\
\text { (9) }\end{array}$ & الموديل & $\begin{array}{l}\text { الدوديل } \\
\text { (7) }\end{array}$ & الموديل & الموديل & الموديل & الموديل & $\begin{array}{l}\text { الموديل } \\
\text { ( 2 }\end{array}$ & $\begin{array}{l}\text { الموديل } \\
\text { ( } 1 \text { ( }\end{array}$ & الناحية التقنية \\
\hline 1.1 & 2.5 & 1.1 & 1.1 & 2.9 & 2.0 & 1.9 & 1.5 & 2.0 & النسيج بيقايا الأقشثة تئ. \\
\hline 1.1 & 2.5 & 1.1 & 1.1 & 2.9 & 2.0 & 1.9 & 2.0 & 2.0 & 2- الكنسوجة ببقايا الأقمشة القطعة \\
\hline 1.6 & 2.5 & 1.1 & 1.1 & 2.9 & 2.0 & 1.0 & 1.5 & 2.0 & 3ـ الموديل وتثكملاته . \\
\hline 1.1 & 3.0 & 1.3 & 1.3 & 3.0 & 3.0 & 1.0 & 2.1 & 3.0 & 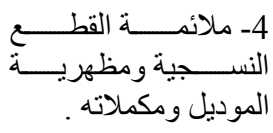 \\
\hline 1.1 & 3.0 & 1.3 & 1.3 & 3.0 & 3.0 & 1.0 & 2.1 & 3.0 & 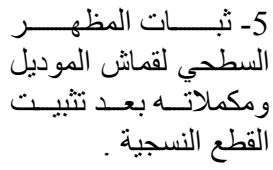 \\
\hline 1.2 & 3.0 & 1.3 & 1.4 & 3.0 & 3.0 & 1.0 & 2.1 & 3.0 & 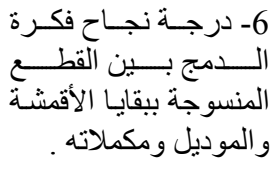 \\
\hline 1.2 & 2.8 & 1.2 & 1.2 & 2.9 & 2.5 & 1.3 & 1.9 & 2.5 & منوسط تقييمات \\
\hline 40.0 & 91.7 & 40.0 & 40.6 & 98.3 & 83.3 & 43.3 & 62.8 & 83.3 & تقبيم الجودة الكلية \\
\hline
\end{tabular}

يتضح من الجدول (15) أن الموديلات ومكملاتها المستخدم فيها المنسوجات اليدويـة المنفذة فئات

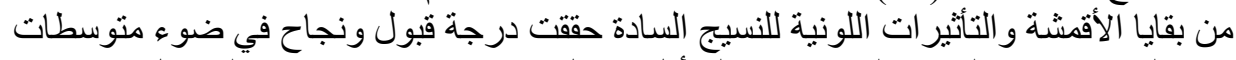

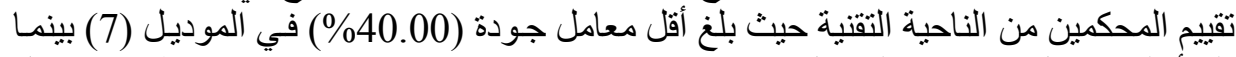

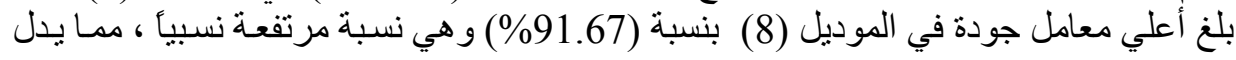


علي وجود علاقة ذات دلالة إحصائية بين استخدام تلك المنسوجات اليدويـة في ملابس الطفل ومكملاتها و إثر اء الناحية التقنية .

رابعاً : الناحية الوظيفية :

\begin{tabular}{|c|c|c|c|c|c|c|c|c|c|}
\hline $\begin{array}{l}\text { العوديل } \\
\text { (9) }\end{array}$ & الموديل & الموديل & $\begin{array}{l}\text { (6) } \\
\text { (6) }\end{array}$ & الموديل & ال الموديل & الموديل & الموديل & الموديل & الناحية الوظيفية الموابع \\
\hline 3.0 & 3.0 & 3.0 & 1.9 & 3.0 & 3.0 & 3.0 & 3.0 & 3.0 & 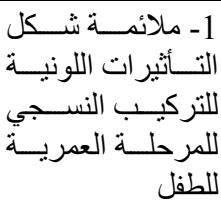 \\
\hline 2.2 & 3.0 & 1.8 & 1.3 & 3.0 & 3.0 & 1.8 & 2.1 & 2.2 & 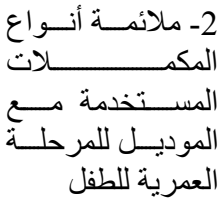 \\
\hline 2.2 & 3.0 & 1.8 & 2.1 & 3.0 & 3.0 & 1.8 & 2.1 & 1.0 & 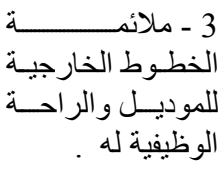 \\
\hline 1.7 & 2.9 & 1.3 & 1.9 & 2.9 & 2.1 & 1.4 & 1.2 & 2.1 & 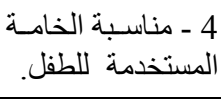 \\
\hline 1.6 & 2.9 & 1.4 & 1.1 & 2.9 & 2.0 & 1.4 & 1.5 & 2.0 & 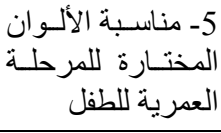 \\
\hline 2.0 & 2.9 & 1.4 & 1.1 & 2.9 & 2.0 & 1.4 & 1.1 & 2.0 & 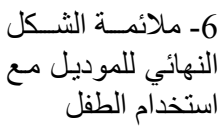 \\
\hline 2.1 & 2.95 & 1.8 & 1.6 & 2.95 & 2.5 & 1.8 & 1.8 & 2.0 & متوسط تقييمات \\
\hline 70.6 & 98.3 & 59.4 & 52.2 & 98.3 & 83.9 & 60.0 & 61.1 & 68.3 & تقييم الجودة الكلية \\
\hline
\end{tabular}

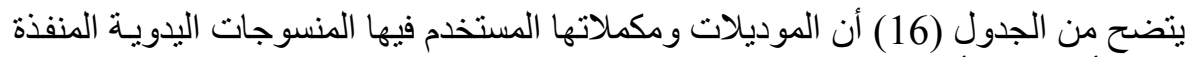

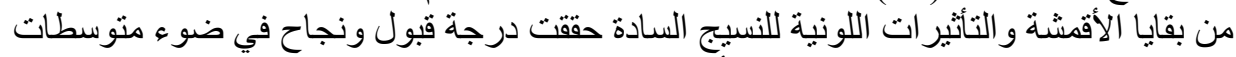

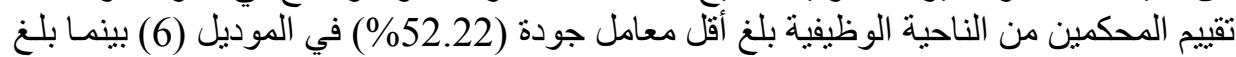

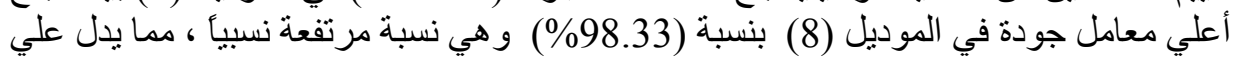




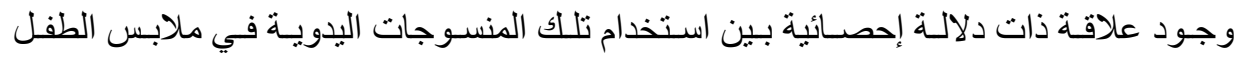
ومكملاتها و إثر اء الناحية الوظيفية الونية

$$
\begin{aligned}
& \text { الفرض الثاني : }
\end{aligned}
$$

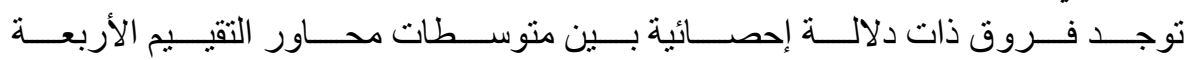

$$
\begin{aligned}
& \text { (تصميمية - جمالية - وظيفية - تقنية) للموديلات إتهات ومكملاتها }
\end{aligned}
$$

جدول (17) يوضح نتائج تحليل التباين الأحادي في اتجاهين Two- way ANOVA لتأثير محاور التقييم والموديلات ومكملاتها المستخدم فيها الإديا المنسوجات اليداتين اليدوية المنفذة من بقايا

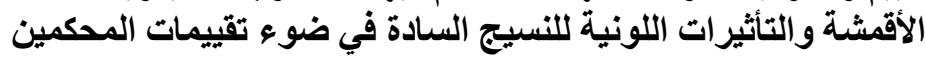

\begin{tabular}{|c|c|c|c|c|c|}
\hline مستوي & "ف" قيمة & المربعات & الحرية & المربعاتوع & التباين \\
\hline .045 & 2.421 & .446 & 8 & 3.564 & الموديلات \\
\hline \multirow[t]{2}{*}{.011} & 4.619 & .850 & 3 & 2.551 & المحاور \\
\hline & & .184 & 24 & 4.418 & الخطأ \\
\hline & & & 35 & 10.533 & المجموع \\
\hline
\end{tabular}

$\mathbf{R}^{2}=0.60$

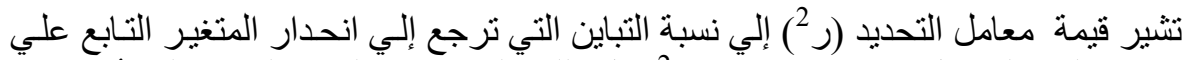

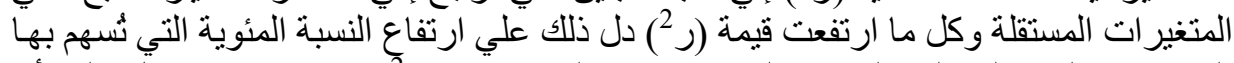

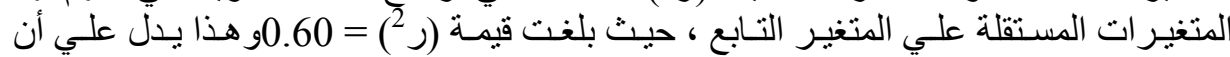

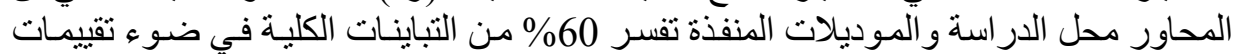

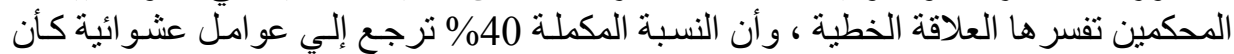

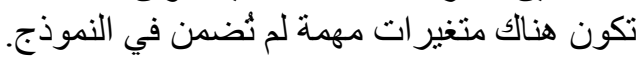

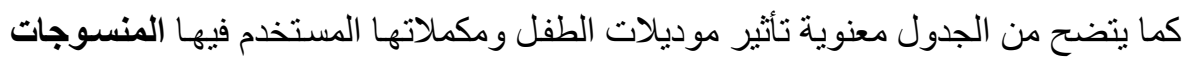

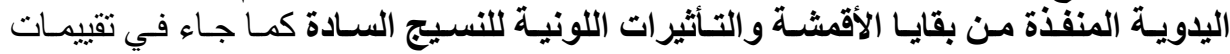
المحكمين حيث بلغت قيمة ف (2.42) و هي دالة إحصائبا عند مستوي الأن 0.05.

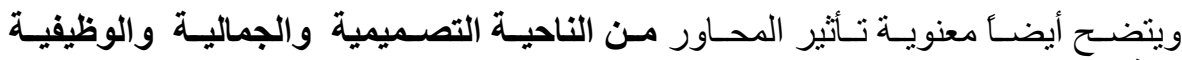

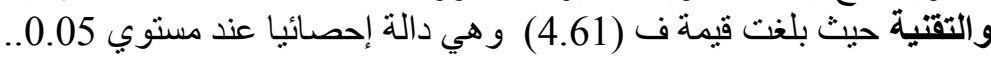

وللتأكد من دلالة الفروق بين محاور التقييم تم تطبيق اختبار Tukey للمقارنات المتعددة بين محاور التقييم وذلالك علي النحو التالي: 
جدول (18) يوضح الفروق بين المتوسطات باستخدام اختبار Tukey للمقارنات المتعددة بين محاور التقييم

\begin{tabular}{|c|c|c|c|c|}
\hline الناحية الجمالية 2.24 & الناحية التقنية 1.94 & الناحية الوظيفية & الناحية التصميمية & \\
\hline$* 0.43$ & $* 0.73$ & $* 0.50$ & & الناحية التصميمية \\
\hline 0.07 & $*^{*} 0.23$ & & & الناحية الوظيفية \\
\hline$* 0.30$ & & & & الناحية التقنية \\
\hline & & & & الناحية الجمالية \\
\hline
\end{tabular}

يتبين من النتائج التي يلخصها الجدول السابق أنه نوجد هناك فروقأ دالة بين كل من:

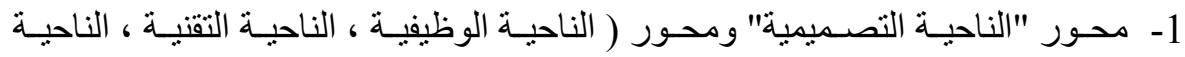
الجمالية) حيث بلغت الفروق بين المتوسطات (0.50، 0.73، 0.43) علي الترتيب و هي دالة النة

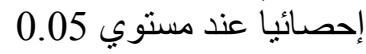

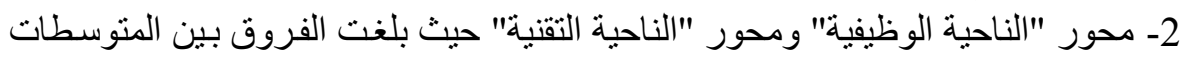

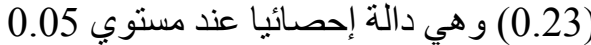
3- محور "الناحية التقنية" ومحور "الناحية الجمالية "حيث بلغت الفياتية الفروق بين المتوسطات 0.05 (0.30) وهي دالة إحصائيا عند مستورئ

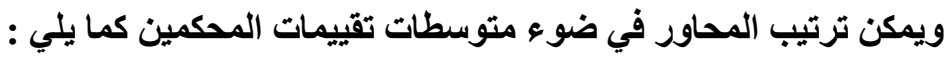
الناحية التصميمية ـ الناحية الجمالية ـ الناحية الوظيفية ـ الناحية التقنية

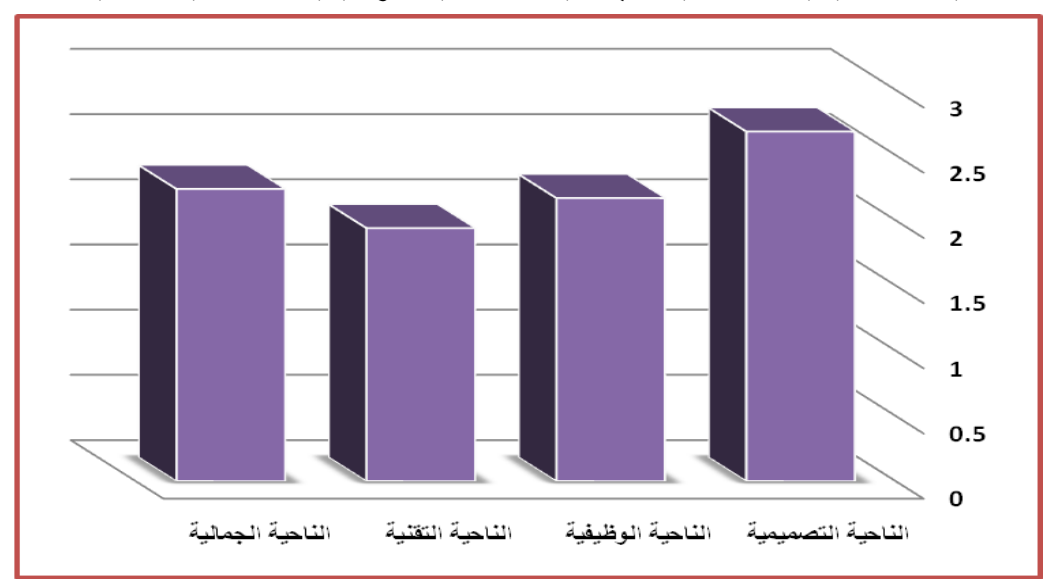

شكل (1) يوضح ترتيب المحاور الأربعة في ضوء تقييمات المحكمين 
توجد علاقة ذات دلالة إحصائية بين استخدام المنسوجات اليدويـة المنفذة من بقائا الأقمشّة

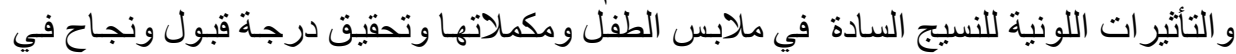

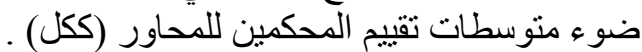

جدول (19) يوضح متوسطات تقييمات المحكمين لمحاور التقييم (ككل) لموديلات الطفل ومكملاتها المستخدم فيها المنسوجات اليدوية المنفذة من بقايا الأقمشة والتأثيرات اللونية التئية

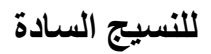

\begin{tabular}{|c|c|c|c|c|c|c|c|c|c|c|c|}
\hline \multirow{2}{*}{ الترتيب } & \multicolumn{2}{|c|}{ (ككل) } & \multicolumn{2}{|c|}{ الناحية الجمالية } & \multicolumn{2}{|c|}{ الناحية التقتية } & \multicolumn{2}{|c|}{ الوظيفية } & \multicolumn{2}{|c|}{ التصميمية الناحية } & \multirow{2}{*}{$\begin{array}{l}\overline{3} \\
\overline{3} \\
3\end{array}$} \\
\hline & الجوودة & المتوسط & تلقودة & المتوسط & تقوييم & المتوسط & تقلقودة & المتوسط & الجوودة & المتوسط & \\
\hline 4 & 77.8 & 9.3 & 70.0 & 2.10 & 83.3 & 2.5 & 68.3 & 2.05 & 89.4 & 2.7 & 1 \\
\hline 5 & 74.8 & 8.97 & 86.1 & 2.6 & 62.8 & 1.9 & 61.1 & 1.8 & 89.4 & 2.7 & 2 \\
\hline 7 & 67.6 & 8.1 & 77.8 & 2.3 & 43.3 & 1.3 & 60.0 & 1.8 & 89.4 & 2.7 & 3 \\
\hline 3 & 82.3 & 9.9 & 72.8 & 2.2 & 83.3 & 2.5 & 83.9 & 2.5 & 89.4 & 2.7 & 4 \\
\hline 2 & 87.8 & 10.5 & 65.0 & 1.95 & 98.3 & 2.95 & 98.3 & 2.95 & 89.4 & 2.68 & 5 \\
\hline 9 & 59.5 & 7.1 & 55.6 & 1.7 & 40.6 & 1.2 & 52.2 & 1.6 & 89.4 & 2.68 & 6 \\
\hline 6 & 70.0 & 8.4 & 91.7 & 2.8 & 40.0 & 1.2 & 59.4 & 1.8 & 89.4 & 2.7 & 7 \\
\hline 1 & 94.3 & 11.3 & 97.8 & 2.9 & 91.7 & 2.8 & 98.3 & 2.95 & 89.4 & 2.7 & 8 \\
\hline 8 & 64.6 & 7.8 & 58.3 & 1.6 & 40.0 & 1.2 & 70.6 & 2.1 & 89.4 & 2.7 & 9 \\
\hline
\end{tabular}

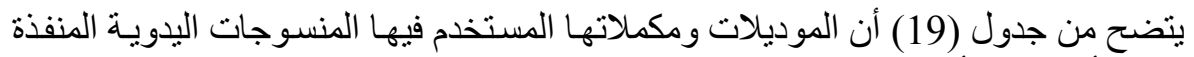

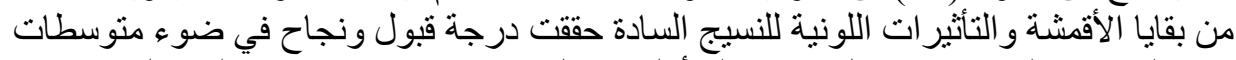

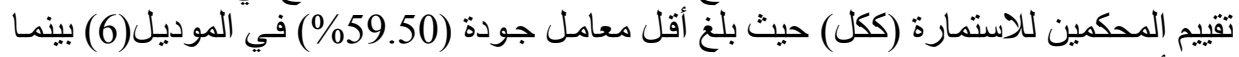

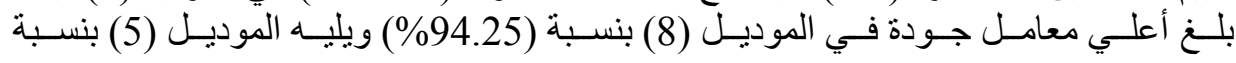


مجلة الاقتصاد المنزلى - مجلد 24 العدد الأول - 2014

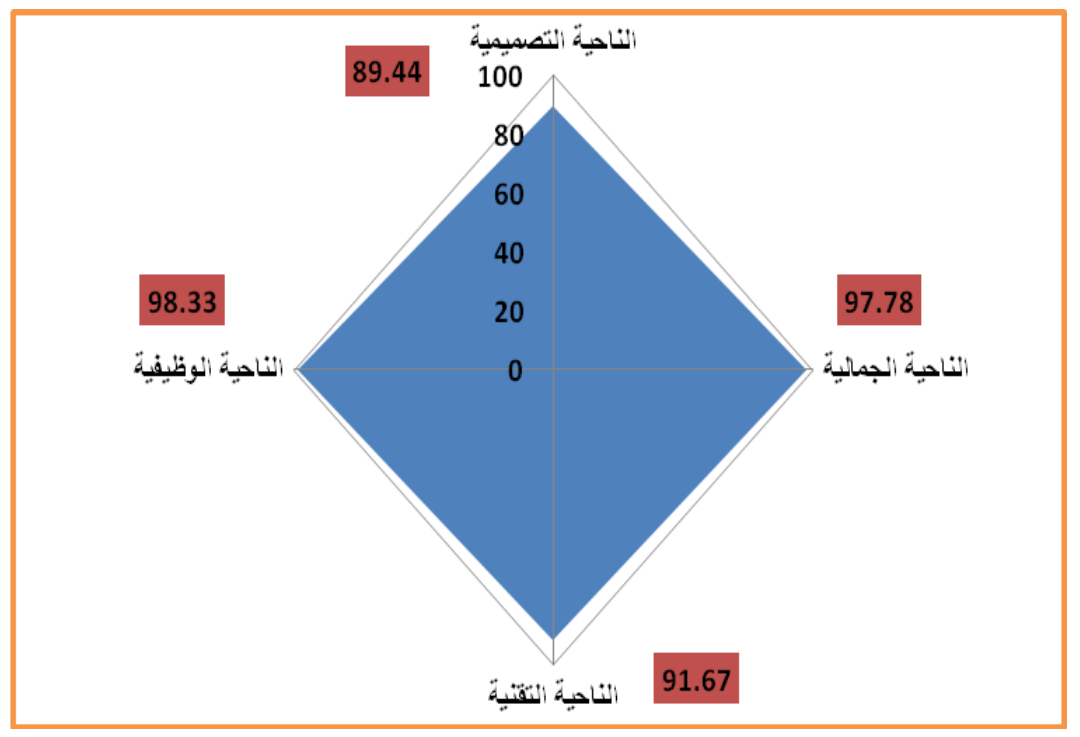

شكل (2) يوضح تقييم الجودة الكلية لأفضل موديل ( رقم 8)

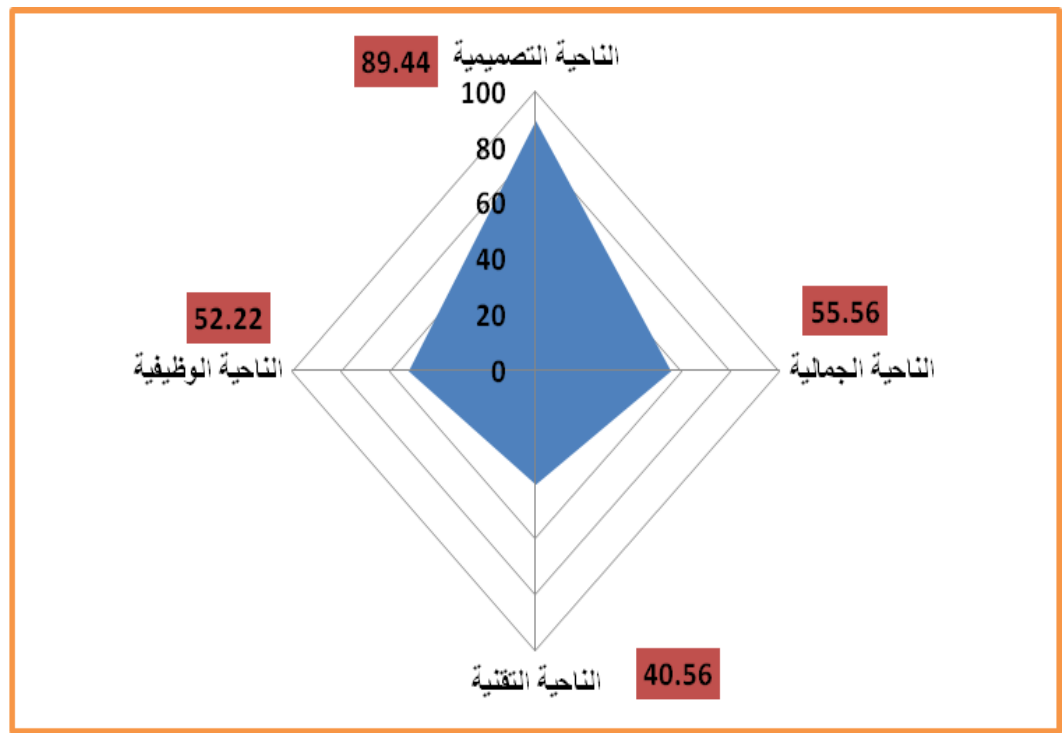

شكل (3) يوضح تقييم الجودة الكلية لأقل موديل ( رقم 6)

- 97 - 


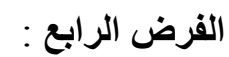

توجد علاقة ذات دلالة إحصائية بين استخدام المنسوجات اليدوية المنفذة من بقايا الأقمشة الئا

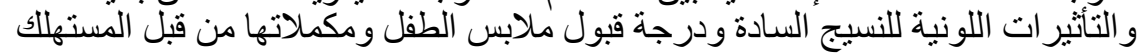

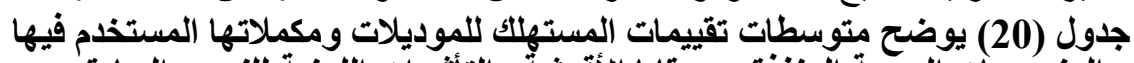
المنسوجات اليذوية المنفذة من بقايا الأقمشة والتئأثيرات اللونية للنسيج السادة

\begin{tabular}{|c|c|c|c|c|c|c|c|c|c|}
\hline 9 & 8 & 7 & 6 & 5 & 4 & 3 & 2 & $\mathbf{1}$ & لالبنود الموديل \\
\hline 2.00 & 3.00 & 2.02 & 2.28 & 2.58 & 2.6 & 2.4 & 2.88 & 2.7 & 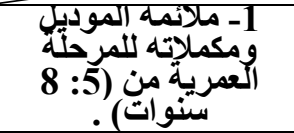 \\
\hline 3.00 & 3.00 & 2.78 & 2.28 & 2.58 & 2.6 & 2.4 & 2.88 & 2.7 & 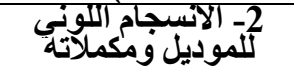 \\
\hline 3.00 & 3.00 & 3.00 & 2.32 & 2.62 & 2.64 & 2.48 & 2.9 & 2.7 & 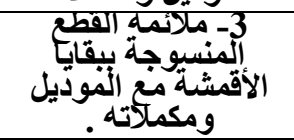 \\
\hline 2.98 & 2.00 & 2.00 & 2.08 & 2.1 & 2.08 & 2.14 & 2.04 & 2.0 & 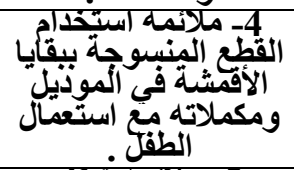 \\
\hline 3.00 & 3.00 & 3.00 & 2.32 & 2.94 & 2.96 & 2.84 & 2.96 & 2.7 & 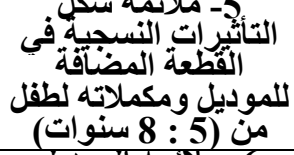 \\
\hline 2.22 & 3.00 & 3.00 & 2.34 & 2.94 & 2.96 & 2.84 & 2.96 & 2.7 & 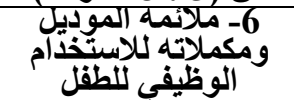 \\
\hline 2.24 & 3.00 & 3.00 & 2.36 & 3 & 3.0 & 2.92 & 2.98 & 2.7 & 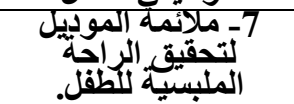 \\
\hline 2.58 & 3.00 & 3.00 & 2.36 & 3 & 3.0 & 2.92 & 2.98 & 2.7 & 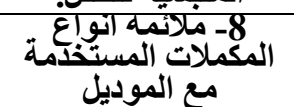 \\
\hline 2.04 & 3.00 & 3.00 & 2.36 & 2.72 & 2.72 & 2.62 & 2.94 & 2.7 & 9- للذبّابِ العام الموديل \\
\hline 2.04 & 3.00 & 3.00 & 2.36 & 2.68 & 2.68 & 2.54 & 2.92 & 2.7 & 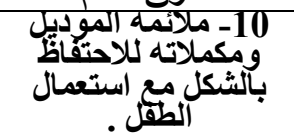 \\
\hline 2.00 & 2.00 & 2.00 & 2.1 & 2.14 & 2.08 & 2.14 & 2.04 & 2.0 & 11- للمسايَضِّة ألموديل \\
\hline 2.00 & 2.00 & 2.00 & 2.1 & 2.04 & 2.0 & 2.0 & 2 & 2 & لكلابكار والتجديد الموديل \\
\hline 2.74 & 3.00 & 3.00 & 2.34 & 2.84 & 2.6 & 2.42 & 2.88 & 2.72 & 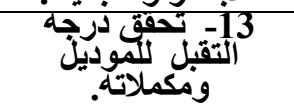 \\
\hline 2.45 & 2.77 & 2.68 & 2.28 & 2.63 & 2.61 & 2.51 & 2.72 & 2.54 & 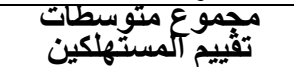 \\
\hline
\end{tabular}

(2.77) و أن الموديل (6) حقق اقل منوسط وكان ( 2.28) . 


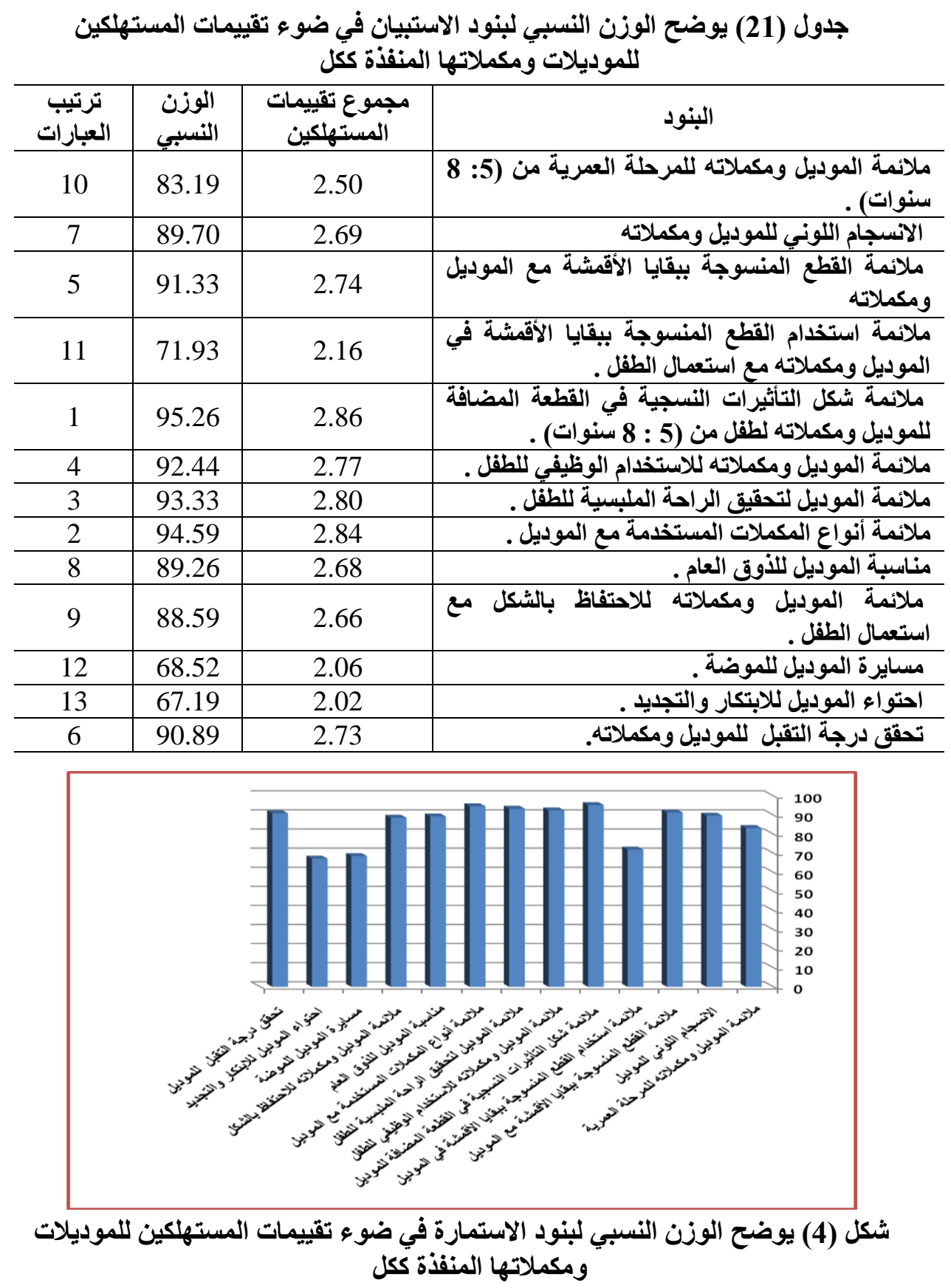


جدول (22) يوضح المتوسطات والانحرافات المعيارية للموديلات المنفذة في ضوء تقييمات المسترهاتكين

\begin{tabular}{|c|c|c|c|c|c|}
\hline أكبر قيمة & أصغر قيمة & الخطأ المعياري & الاتحراف المعياري & المتوسط & الموديل \\
\hline 2.72 & 2.00 & .08540 & .30790 & 2.5400 & 1 \\
\hline 2.98 & 2.00 & .11010 & .39699 & 2.7200 & 2 \\
\hline 2.92 & 2.00 & .08526 & .30741 & 2.5123 & 3 \\
\hline 3.00 & 2.00 & .09810 & .35371 & 2.6092 & 4 \\
\hline 3.00 & 2.04 & .09456 & .34094 & 2.6292 & 5 \\
\hline 2.36 & 2.08 & .03003 & .10827 & 2.2769 & 6 \\
\hline 3.00 & 2.00 & .13038 & .47010 & 2.6769 & 7 \\
\hline 3.00 & 2.00 & .12163 & .43853 & 2.7692 & 8 \\
\hline 3.00 & 2.00 & .12221 & .44065 & 2.4492 & 9 \\
\hline
\end{tabular}

one- way ANOVA جدول (23) يوضح نتائج تحليل التباين الأحادي في اتجاه للفروق بين تقييمات المستهلكين للموديلات ومكملاتها المنفذة التهاين

\begin{tabular}{|c|c|c|c|c|c|}
\hline مستوي الدلالة & قيمة "ف" & متوسطات & الحرجية & المربعوات & مصدر التباين \\
\hline \multirow[t]{3}{*}{.031} & \multirow[t]{3}{*}{2.217} & .297 & 8 & 2.380 & بين المجموعات \\
\hline & & .134 & 108 & 14.489 & داخل المجموعات \\
\hline & & & 116 & 16.869 & التباين الكلي \\
\hline
\end{tabular}

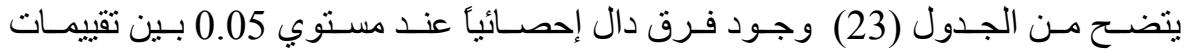
المستهلكين للموديلات المنفذة ومكملاتها حيث بلغت قيمة ف (23.217) و هي دالة إحصـيائياً عند

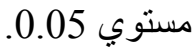

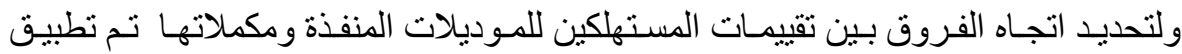

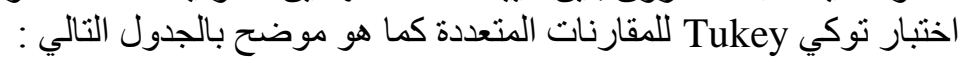
جلول (24) يوضح الفروق بين المتوسطات باستخدام اختبار توكي Tukey للمقار المارنات

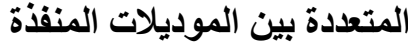

\begin{tabular}{|c|c|c|c|}
\hline الالالة & الفروق بين المتوسطات & \multicolumn{2}{|c|}{ الموديلات } \\
\hline .942 & $-.180-$ & الثاني & \multirow{8}{*}{ الأول } \\
\hline 1.000 & .027 & الثالث & \\
\hline 1.000 & -.069- & الرابع & \\
\hline .999 & -.089 & الخامس & \\
\hline .662 & .263 & السادس & \\
\hline .989 & -.136- & السابع & \\
\hline .805 & -.229 & الثامن & \\
\hline .999 & .090 & التاسع & \\
\hline .877 & .207 & الثالث & الثانى \\
\hline
\end{tabular}




\begin{tabular}{|c|c|c|c|}
\hline .997 & .110 & الرابع & \\
\hline .999 & .090 & الخامس & \\
\hline .062 & .443 & السـادس & \\
\hline 1.000 & .043 & السابع & \\
\hline 1.000 & -.049- & الثامن & \\
\hline .626 & .270 & التاسع & \\
\hline .999 & -.096- & الرابع & \multirow{6}{*}{ الثالث } \\
\hline .996 & -.116- & الخامس & \\
\hline .781 & .235 & السادس & \\
\hline .966 & -.164- & السابع & \\
\hline .690 & $-.256-$ & الثامن & \\
\hline 1.000 & .063 & التاسع & \\
\hline 1.000 & $-.020-$ & الخامس & \multirow{5}{*}{ الرابع } \\
\hline .344 & .332 & السادس & \\
\hline 1.000 & -.067- & السابع & \\
\hline .971 & $-.160-$ & الثامن & \\
\hline .971 & .160 & التاسع & \\
\hline .267 & .352 & السادس & \multirow{4}{*}{ الخامس } \\
\hline 1.000 & $-.047-$ & السـابع & \\
\hline .987 & $-.140-$ & الثامن & \\
\hline .942 & .180 & التاسع & \\
\hline .132 & $-.400-$ & السـابع & \multirow{3}{*}{ السادس } \\
\hline .023 & $-.492-*$ & الثامن & \\
\hline .955 & -.172- & التاسع & \\
\hline .999 & -.092- & الثامن & \multirow{2}{*}{ السابع } \\
\hline .811 & .227 & التاسع & \\
\hline .396 & .320 & التاسع & الثامن \\
\hline
\end{tabular}

ويمكن ترتيب الموديلات في ضوء متوسطات تقييمات المستهلكين باستخدام اختبار نوكي Tukey

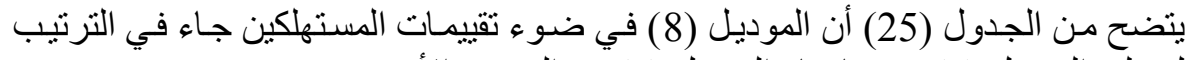

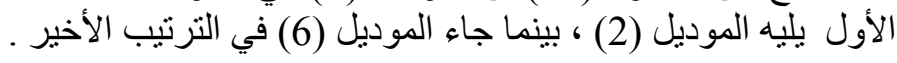


جدول (25) يوضح ترتيب الموديلات المنفذة في ضوء تقييمات المستهلكين باستخدام

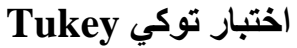

\begin{tabular}{|c|c|c|}
\hline \multicolumn{2}{|c|}{ Subset for alpha $=0.05$} & \multirow{2}{*}{ الموديلات } \\
\hline 2 & 1 & \\
\hline & 2.2769 & السادس \\
\hline 2.4492 & 2.4492 & التاسع \\
\hline 2.5123 & 2.5123 & الثالث \\
\hline 2.5400 & 2.5400 & الأول \\
\hline 2.6092 & 2.6092 & الرابع \\
\hline 2.6292 & 2.6292 & الخامس \\
\hline 2.6769 & 2.6769 & السابع \\
\hline 2.7200 & 2.7200 & الثاني \\
\hline 2.7692 & & الثامن \\
\hline .396 & .062 & الالالة \\
\hline
\end{tabular}

توجد علاقة ارنباطية بين ترتيب المتخصصين و غير المتخصصين للموديلات ومكملاتها

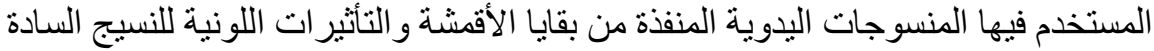

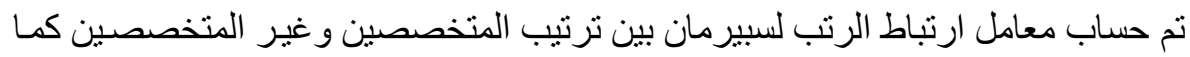

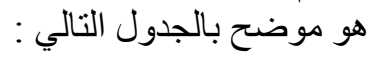

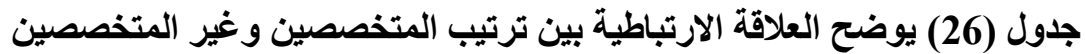

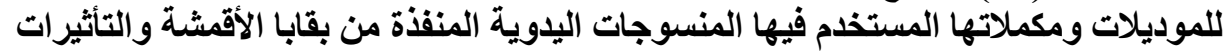
اللونية للنسيج السادة الباتة

\begin{tabular}{|c|c|c|c|}
\hline العلاقة الارتباطية & ترتخيب غير & المتخصصين & الموديل \\
\hline \multirow{9}{*}{ 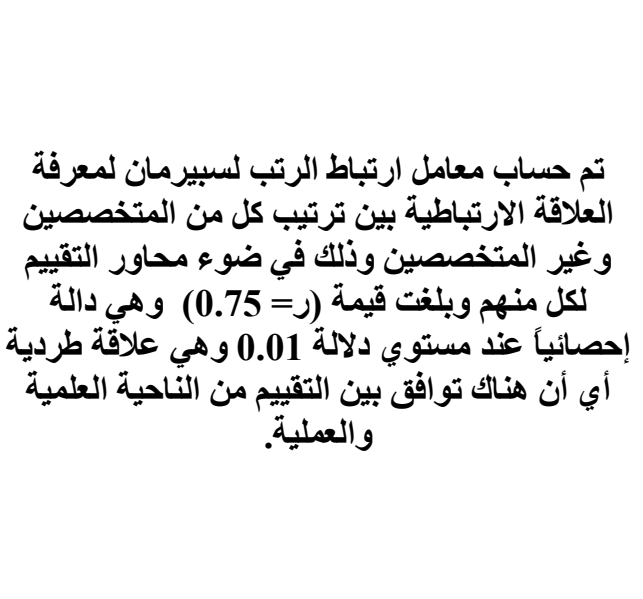 } & 6 & 4 & الأول \\
\hline & 2 & 5 & الثاني \\
\hline & 7 & 7 & الثالث \\
\hline & 5 & 3 & الرابع \\
\hline & 4 & 2 & الخامس \\
\hline & 9 & 9 & السادس \\
\hline & 3 & 6 & السابع \\
\hline & 1 & 1 & الثامن \\
\hline & 8 & 8 & التاسع \\
\hline
\end{tabular}


يتضـح مـن الجـدول ( 26) أنـهـ توجـد علاقـة ارتباطيـة بـين ترتيـب المتخصصسين و غيـر

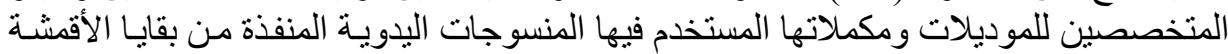

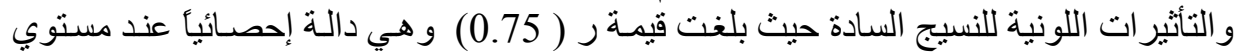
دلالة 0.01.

\section{بعد معالجة البيانات إحصائياً يتبين التالتي :}

\section{ملخص نتائج البحث :}

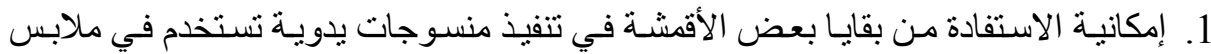

الطفل و مكملاتها.

2. إمكانية الاستفادة من التأثير ات اللونية للنسيج السادة في إثر اء ملابس الطفل ومكملاتها.

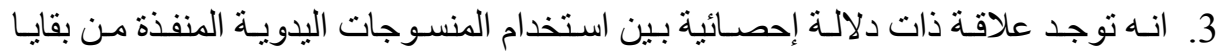

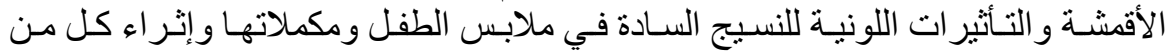

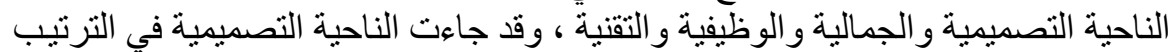
الأول يليها الجمالية ثم الوظيفية ثم التقنية.

4. أنـه توجد علاقـة ذات دلالــة إحصـائية بين استخدام المنسـوجات اليدويـة المنفـذة مـن بقايـا

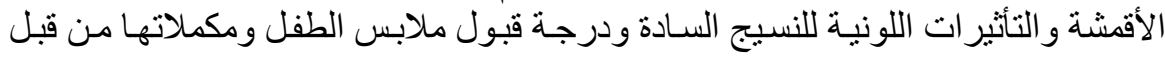

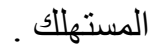
توصيات البحث :

$$
\text { يوصي البحث بما يلي : }
$$

1. التأكيد علي أهميـة تو اصـل البحـوث التجريبيـة التي تهـدف إلـي الإفـادة مـن بقايـا الأقمشـة

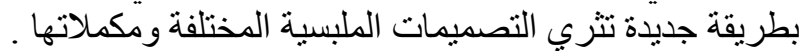

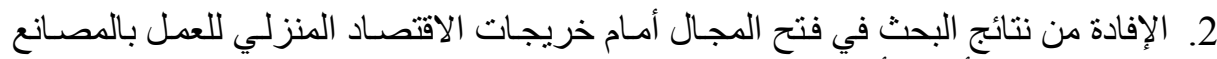

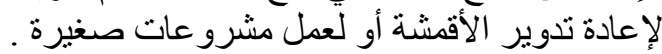

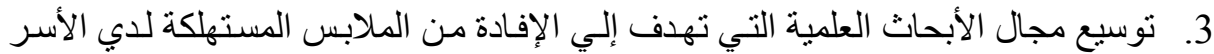

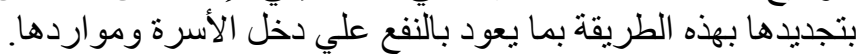

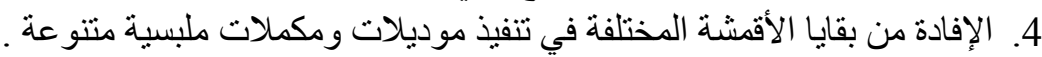

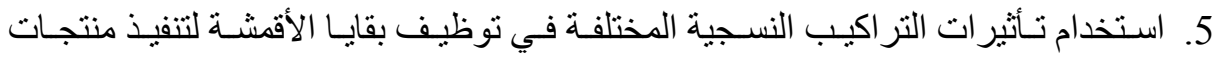

$$
\text { متنو عة. }
$$

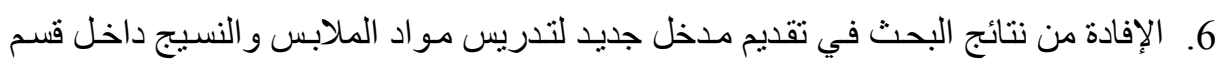

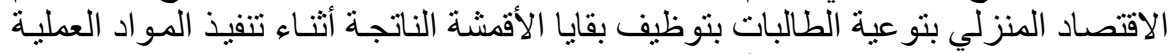

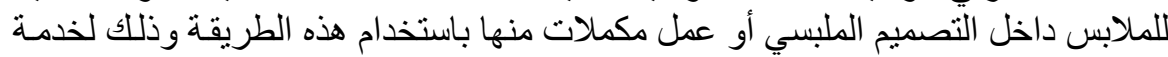
الجانب الجمالي و الاقتصادي للملبس. 
1.أشرف عبد الفتاح مصطفي (2005) : بو اقي المنسوجات ولغة التعبير الفني ، مجلة بحوث

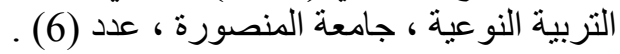

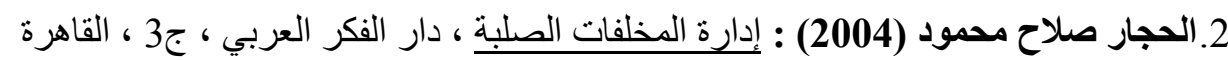

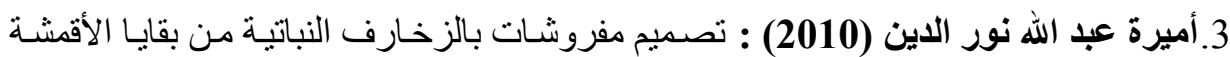
و إمكانية استفادة الأسر المنتجة منها ، مجلة بحوث التربية النوعية ، جامعة المنصورة ، عدد (18) . ع إنغانة

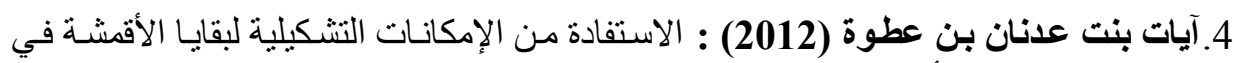

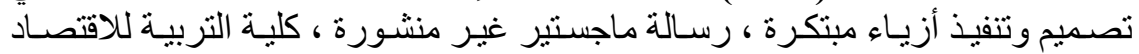

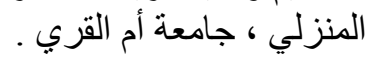

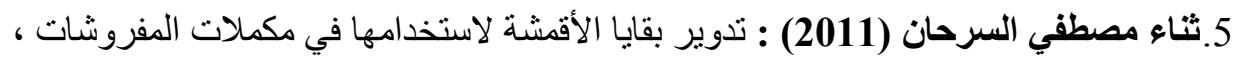

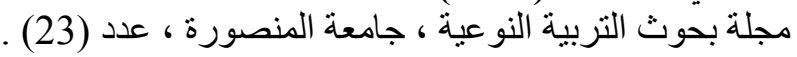

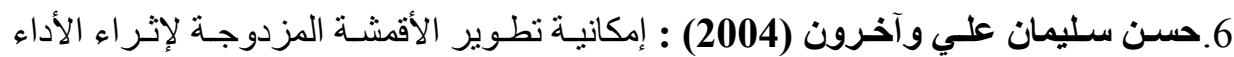

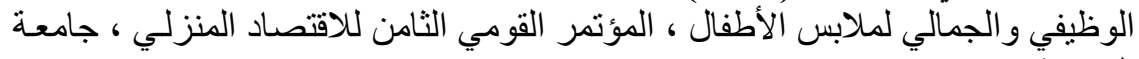

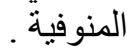

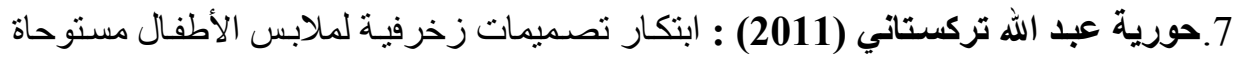

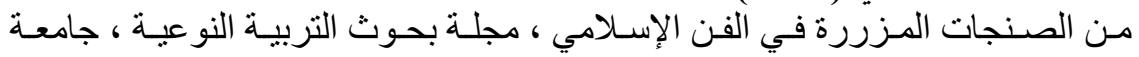

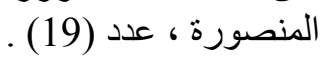

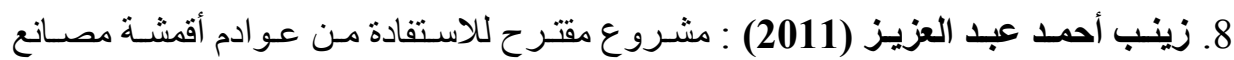

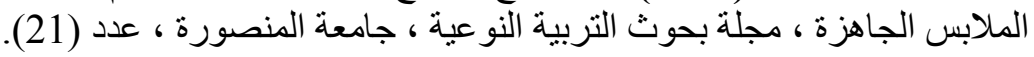

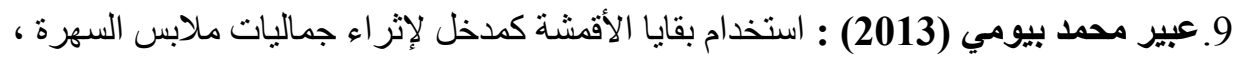

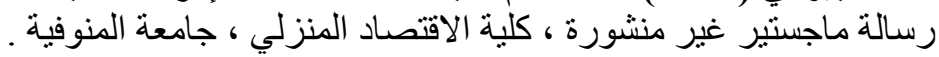

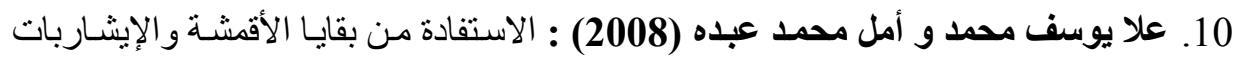

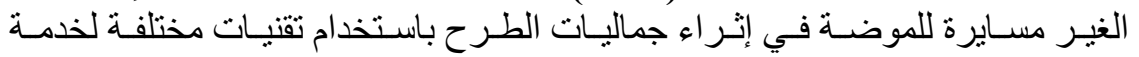

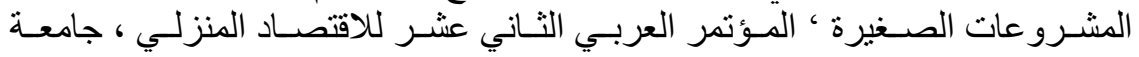

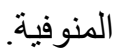

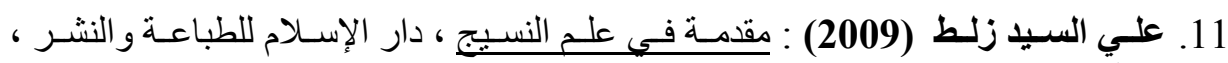

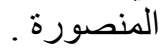
12. نادية محمود خليل (1998) : در اسة الأسس العلمية و الفنية لتجاور بقايا الأقمشة في تنفيذ

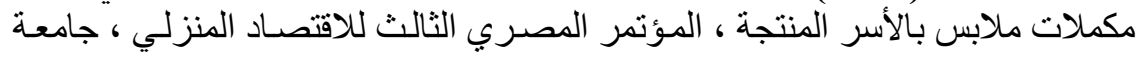

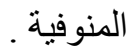


13. P.V.Vidyasagar (1998) : Hand Book Of Textiles, Mittal Publications, India.

14. Wang, Youjiang (2006) : recycling in textiles, Woodheed publishing LTD, Cambridge, England

15. Available at "http://tech4eco.blogspot.com"- accessed 27, 11,2012

16. Available at" http://www.iasj.net/iasj?" accessed 26, 4,2014 .

17. Available at " http://www.arab-ency.com/index.php?" accessed 22, 4,2014 . 
ملحق رقم (1)

استمارة تقييم السادة المحكمين للموديلات ومكملاتها المنفذة

\begin{tabular}{|c|c|c|c|}
\hline \multicolumn{3}{|c|}{ الموديل (1) } & \multirow[b]{2}{*}{ أوجه التقييم } \\
\hline \multirow{2}{*}{ ملانم } & \multirow{2}{*}{ 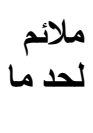 } & \multirow[t]{2}{*}{ ملائم } & \\
\hline & & & أولاً : الجانب التصميمي \\
\hline & & & وبين باقي أجزاء الموديل . توبط بين القطع المنسوجة للموديل ومكملاته \\
\hline & & & الأقمثة و تحقى النسبة وديل ومكملاته . بين مسـاحة القطعة المنسوجة من بقايـا \\
\hline & & & 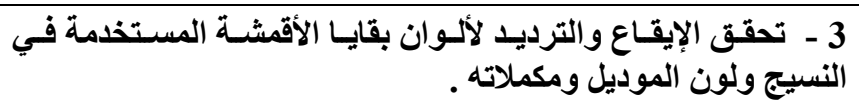 \\
\hline & & & 4 - ـ تحقق التوازن والتوافق بين خامة بقايا الأقمشة مع خامة قمـاش \\
\hline & & & 5- ت تحقق التصميم من خلال الدمج بين القطع المنسوجة وباقي أجزاء \\
\hline & & & 6 - ملائمة تصميم الموديل للطقل من (5 : 8 سنوات) . \\
\hline & & & ثانياً : الجاتب الجمالي \\
\hline & & & 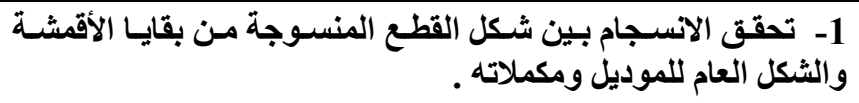 \\
\hline & & & 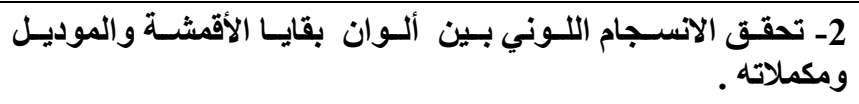 \\
\hline & & & 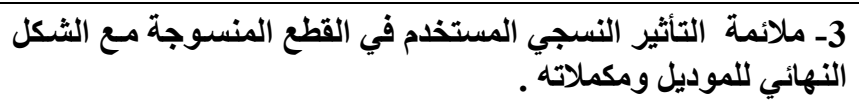 \\
\hline & & & 4- ملائمة أنواع المكملات باستخدام القطع النسجية مع الموديل . \\
\hline & & & 5- الجدة و الحداثة في تثكيل وتوزيع النسيج علي الموديل ومكملاته \\
\hline & & & 6- ملائمة الثكل العام للموديل ومكملاته مع الموضة . \\
\hline & & & ثالثاً : الجانب التقتي \\
\hline & & & 1- تحقى الدقة في تنفيذ النسيج بقايا الأقمشة . \\
\hline & & & 2- درجة انتظام القطعة المنسوجة بيقايا الأقشة . \\
\hline & & & 3- جودة تثبيت النسيج مع الموديل ومكملاته . \\
\hline & & & - $106-$ \\
\hline
\end{tabular}


مجلة الاقتصاد المنزلى - مجلد 24 العدد الأول - 2014

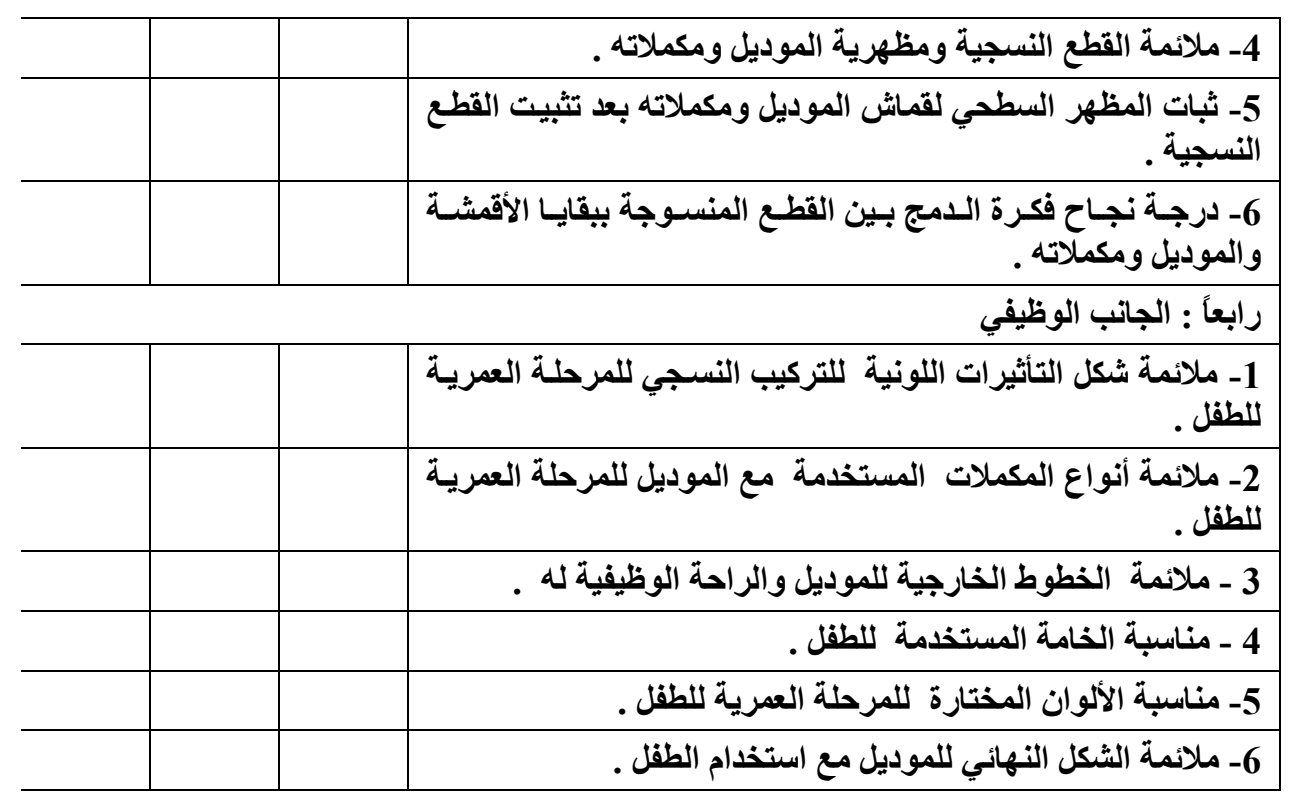




\section{ملحق رقم (2)}

استمارة تقييم المستهلكين للموديلات ومكملاتها المنفذة

\begin{tabular}{|c|c|c|c|}
\hline \multicolumn{3}{|c|}{ 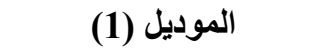 } & \multirow[b]{2}{*}{ أوجه التقييم } \\
\hline 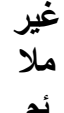 & 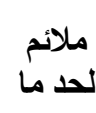 & 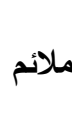 & \\
\hline & & & 1- ملائمة الموديل ومكملاته للمرحلة العمرية من (5 :8) سنوات). \\
\hline & & & 2- الانسجام اللوني للموديل ومكملاته . \\
\hline & & & 3- ملائمة القطع المنسوجة بيقايا الأقمشة مع الموديل ومكملاته . \\
\hline & & & 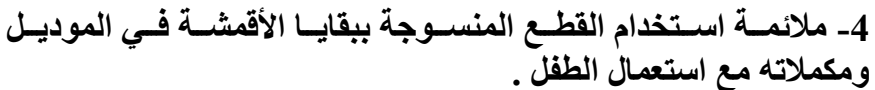 \\
\hline & & & 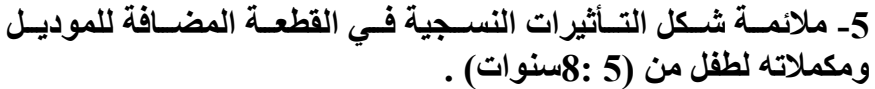 \\
\hline & & & 6- ملائمة الموديل ومكملاته للاستخدام الوظيفي للطقل . \\
\hline & & & 7- ملائمة الموديل لتحقيق الراحة الملبسية للطقل. \\
\hline & & & 8- ملائمة أنواع المكملات المستخدمة مع الموديل . \\
\hline & & & 9- مناسبة الموديل للذوق العام . \\
\hline & & & 10- ملائمة الموديل ومكملاته للاحتفاظ بالشكل مع استعمال الطقل. \\
\hline & & & 11- مسايرة الموديل للموضة . \\
\hline & & & 12- احتواء الموديل للابتكار والتجديا . \\
\hline & & & 13- تحقق درجة التقبل للموديل ومكملاته. \\
\hline
\end{tabular}




\title{
The Benefit Of The Remains Of Some Fabrics By Using The Handmade Textile In Enriching The Clothes Of The Child And Its Completions
}

\begin{abstract}
The current research is interested in applying new technique style to use the remains of fabrics, its usage in making manual textiles which are used in designing the clothes, where these textiles achieve useful and beautiful values and widen the horizon in front of the designer in order to do creative and different designs which are suitable and cope with the product through the material and different weave structures. Because the clothes of the children need anew entrance and rich elements based on the new and the creation in its design that gives anew shape to the child. employing the beautiful and artist value for the manual textiles contributes in appearing the clothes for the children and its completion through the different colorful and weave effects .

Thus, the current research aims at the ability of the usage of the remains of fabrics in running the manual textiles with different shape and colorful effects by using the plain weave and by employing these manual textiles with the beautiful value in enriching the clothes of the child and its completions, has been implementing nine models and its completions suitable for the female children at the age of $5: 8$ years have already been done by using the manual textiles done from the remains of Lycra , Jersey, single fabrics and the colorful effects of the plain weave in designing these models . a form of questionnaire has already been prepared to estimate the functional, technical, beautifully, designable side of these models and its completions by the expertise's . an other form of value for the consumer to know the rate of degree of accepting these models and its completions .
\end{abstract}

Through treating the data statistically, the results showed the ability of benefiting from the remains of some fabrics and the colorful effects of plain weave in running out manual textiles which are used in enriching the clothes of the child and its completions, that study recommended with the certainty of the importance of continuing the experiment researches which aim at the benefit of the remains of fabrics in anew manner, which enriches the different clothes designs and its completions . that opens the field in front of the home economic graduates for working in the factories to recycle the fabrics or for doing 
small projects, and the usage of the effects of different weave structures in employing the remains of fabrics to carry out different products, as well as, the benefit of the results of the research in presenting anew entrance to teaching the subjects of the clothes and the textile inside the department of home economic by know the students employ the remains of fabrics resulted from the practical materials of the clothes inside the clothes design or doing its completions by using that method, that's for the beautifully and economical side of the clothes . 